Николина Тутуш

(Филозофски факултет, Нови Сад)
Изворни научни рад

УДК 811.163.41'374"1830" Radović K.

DOI 10.19090/ppj.2019.50.47-83

\title{
РЕЧНИК ФИТОНИМА У ЛЕКАРУШИ КОСТЕ РАДОВИЋА $(1830)^{1}$
}

\section{САЖЕТАК}

У раду се представља рукописна лекаруша са молитвеником Косте Радовића из 1830. године, која се чува у Одељењу раритета Матице српске, под сигнатуром PP II 62. Циљ истраживања односи се на сагледавање предстандардног језичког израза на лексичком нивоу и на састављање речника фитонима заступљених у овом рукопису. Као резултат добија се систематизован преглед биља које се код нас употребљавало за лечење, као и преглед језичког фонда везаног за њихово именовање. Поређењем са старијим, средњовековним медицинским списима, као што су Ходошки зборник и Хиландарски типик, настоји се осветлити потенцијална повезаност овог рукописа са делима сличне намене ранијег периода, при чему се као критеријуми узимају организација текста, број и истоветност биљних врста, њихових назива и лековита дејства која им се приписују.

КљУЧНЕ РЕЧИ: рукописна лекаруша са молитвеником, Коста Радовић, 19. век, речник фитонима.

\section{1. Лековито биље и лекаруше у српској култури}

Употреба лековитог биља сматра се најстаријим начином лечења болести, ${ }^{2}$ једним од најранијих људских искустава које се развијало упоредо

${ }^{1}$ Прилог је настао као резултат истраживања на докторским студијама на предмету Историја српског књижевног језика: предстандардни период под менторством проф. др Исидоре Бјелаковић.

2 „Немајући непосредних података о другим начинима и средствима лечења, и позивајући се на вештину лечења помоћу лековитих трава код данашњих дивљих 
са коришћењем биља у исхрани (Бојанин 2012: 7). Примена лековитог биља у лечењу представља значајну етапу и у развоју српске медицине - о распрострањености и развијености, као и дугом временском периоду у ком је лековито биље имало првенство, сведоче сачувани кодекси са рецептима, тзв. лекаруше. ${ }^{3}$ Највећим својим делом лекаруше су распрострањене у рукописној традицији и најчешће се налазе у рукописним књигама разноврсног садржаја (Бојанин 2012: 18). Порекло српских лекаруша препознатљиво је у народним византијским кодексима, ијатрософијама, чије преводе заправо представљају (Бјелаковић 2003: 7), а који се доводе у везу са тековинама античке медицине. ${ }^{4}$ Њихова употреба најзаступљенија је током средњег века, с тим да се лекаруше код нас чувају, преписују и користе и након пропасти средњовековне државе, све до краја XIX века.

Два најзначајнија дела српске културе, када је о реч о медицинским терапијским кодексима са рецептима за лечење, јесу Ходошки зборник (1309) и Хиландарски медицински кодекс (средина XVI века). Њихова важност огледа се у чињеници да су они потврда да је српска средњовековна медицина била у тесној вези са вештином лечења латинског запада и

народа, многи историчари закључују, по аналогији, да је и преисторијски човек примењивао лековито биље за лечење болести“ (Станојевић 1953: 4).

${ }^{3}$ У Jugoslovenskoj bibliografiji lekaruša i narodnih medicinskih rukopisa из 1973. године Јаша Романо представља 415 лекаруша са простора старе Југославије, насталих у периоду од XIII до XIX века, с тим да овај број није коначан. Примера ради, лекаруша Косте Радовића, која је предмет истраживања овог рада, не налази се у поменутој библиографији, иако је шире одређено место њеног порекла, Војводина, обрађено. Може се претпоставити да овај случај није усамљен.

4 „Od Galena, konsultovanje knjiga sa receptima postaje najvažniji deo lekarske prakse“ (Čeperković 2005: 83). Битно је напоменути да су лекаруше, иако широко распрострањене и коришћене у народу, заправо у непосредној вези са средњовековном научном медицином заснованом на античким и арапским традицијама (Бојанин 2012: 21). У том смислу, оне су показатељ да је српска средњовековна медицина ишла у корак са византијском и западноевропском. Међутим, са развојем савремене медицине, од краја XVIII века, присутност и коришћење лекаруша упућују на извесну заосталост медицинске праксе у односу на тековине светске медицине, због чега бивају посматране и класификоване искључиво као део народне медицине (Бојанин 2012: 20-21). 
византијског истока. ${ }^{5}$ У оквиру тих средњовековних рукописа налазе се наше најстарије лекаруше. Предузета истраживања показују да постоји извесна сличност између наших старијих, средњовековних, и новијих терапијских кодекса, с обзиром на постојање истих рецепата и назива обољења и на истоветност прескрипције неких рецепата (Катић 1957: 114). С тим у вези је и средњовековно схватање узрока болести које се ослања на учење о соковима и елементима од којих се састоји свако живо тело, преузето из античке школе Галена и Хипократа, ${ }^{6}$ а које се задржало и у лекарушама које датирају из XIX века, времена када је у медицини такво учење било превазиђено.

Закључак до кога се долази јесте да новији терапијски кодекси српске народне медицине представљају проширене или скраћене терапијске кодексе народне средњовековне медицине, а да је такво стање ствари последица историјских околности, при чему се пре свега мисли на пропаст српске средњовековне државе и живот под туђинском влашћу, турском, као и аустроугарском (Катић 1957: 114-115). Такво стање ствари утицало је на опстанак народне медицине, која се очувала и у XIX веку, а коју потврђује управо постојање лекаруша из тог периода.

\section{2. Предмет и задаци истраживања}

Предмет овог истраживања јесте рукописна лекаруша са молитвеником Косте Радовића, настала у Кикинди 1830. године. ${ }^{7}$ На њеним првим страницама стоји податак да је реч о препису књиге извесне госпоже Хелене Папич. Овај рукопис може се, према садржају, условно поделити на три дела

5 У Хиландарском медищинском кодексу налазе се преписи различитих средњовековних трактата из фармакотерапије и различитих области медицине, а међу њима и салернски приручник Liber de simplici medicina Матеје Платеаријуса и Antidotarium извесног Николе из Салерна, оба из XII века (Бојанин 2012: 10-11).

${ }^{6}$ Према овом учењу свако живо тело састоји се од крви, слузи, црвене и црне жучи, а ови сокови одговарају основним елементима материјалног света, ваздуху, земљи, води и ватри. Њихова неравнотежа сматра се узроком сваке болести, а оздрављење се постиже одстрањивањем сувишне течности из организма (Бјелаковић 2003: 5-6). Заступљеност тог учења видљива је и у лекаруши Косте Радовића.

7 Лекаруша са молитвеником Косте Радовића чува се у Одељењу раритета Матице српске, под сигнатуром РP II 62. 
- први део односи се на практичне савете везане за одржавање домаћинства и припрему појединих напитака, други би се могао одредити као молитвеник, док трећи део, од 38. до 73. листа рукописа, јесте текст лекаруше.

Уочљива је и разлика на пољу организације текста саме лекаруше - прво су азбучним редоследом навођени називи одређених биљних врста, притом обележени и одговарајућим редним бројем, а испод таквог наслова налази се текст рецепта који читаоца обавештава о болестима које наведена биљка лечи и начину справљања лека (мелема, облога, напитка, инхалација, уља, течности за купање, испирање и укапавање, прашкова). Такво решење присутно је од 38. до 61. листа, односно од првог до 93. записа, након чега, готово доследно, наслови записа бивају носиоци податка о којој болести је реч (нпр. Рецептъ $\bar{G}$ Срдоболь), док се у тексту рецепта наводе биљке које се користе за справљање лека.

Циљ истраживања односи се, с једне стране, на сагледавање предстандардног језичког израза на лексичком нивоу и на састављање речника фитонима заступљених у овом рукопису, док, с друге стране, на сагледавање лековитог својства које се приписивало именованим биљкама и њиховог односа са данашњом научном мисли. ${ }^{8}$ Као резултат добија се један систематизован преглед лековитог биља које је се код нас користило, као и преглед језичког фонда везаног за њихово именовање и именовање њихових вегетативних делова, уопштено (корен, лист, плод, семе) и одређеније (посебни називи за плод одређених биљних врста).

\section{3. О начину састављања речника фитонима}

Приликом састављања речника фитонима у лекаруши Косте Радовића водили смо се начелима предложеним у раду „Концепција дијахронијског терминолошког речника“ Исидоре Бјелаковић и Љиљане Суботић (Бјелаковић - Суботић 2011: 149-162). Одредницу чине следећи елементи: транскрибован фитоним из лекаруше, њен латински назив, забележена

\footnotetext{
8 У ту сврху, настојали смо да у оквиру значења фитонима наведемо који су то, према данашњим научним истраживањима, лековити делови одређене биљке и лековита својства која им се у лекаруши Косте Радовића приписују. На тај начин добија се информација о степену њиховог подударања или неподударања.
} 
графијска форма у оригиналу, савремени назив одређене биљне врсте (уколико је неопходан), значење фитонима, контекст, синоними. Годину нисмо наводили, с обзиром на то да је реч о само једном извору грађе. Преузели смо затечену пагинацију рукописа, с тим да смо уз сваки лист наводили и информацију о страни (a, б). Изостављени делови записа обележавани су на следећи начин: [...], а нерашчитани делови текста помоћу облих заграда: (...). Реконструисан графијски израз фитонима чија потврда није забележена у тексту маркиран је звездицом *.

Латинске називе биљака одређивали смо користећи ботаничке речнике Д. Симоновића (1959) и Б. Шулека (Šulek 1879), с тим да смо предност давали Симоновићу, јер је савременији и обухватнији (у његовој грађи је и Шулеков речник). С обзиром на то да се код Симоновића проналази више латинских назива за једну биљну врсту, тамо где на основу описа биљке датог у лекаруши није било могуће одредити који би латински назив одговарао наведеној биљци, наводили смо све латинске називе које смо пронашли као могућа решења, с тим да смо подвлачили оне на које се опис биљке дат као значење наведеног фитонима односи. Тамо где је било могуће са сигурношћу изабрати један од више наведених латинских назива, сужавали смо избор, остављајући објашњење у фусноти. Последица оваквог поступка јесте непотпуна одређеност, али смо сматрали да је са научне стране тако исправније поступити. Несигурно одабирање једног латинског назива могло би значити и погрешан избор, тј. погрешно значење наведеног фитонима.

Значење фитонима наводили смо према J. Туцакову (1997), Д. Симоновићу (1959), А. Савићу (2014), Н. Драгин (2014) и Речнику српскохрватског књижевног језика, с тим да смо предност давали Туцакову, jep је он најобухватнији и најпрецизнији (Шулек не даје објашњења, Симоновић понегде). Значења оних фитонима које нисмо проналазили код Туцакова, Симоновића, Савића и Драгин, тражили смо у Речнику. Више различитих аутора у оквиру једне одреднице наводили смо само онда када је то било неопходно ради добијања потпуне информације. У случајевима где би дошло до извесног преклапања то нисмо радили. За поједине фитониме, које нисмо пронашли у наведеној литератури, наводили сам значење које се може одредити на основу записа у лекаруши (нпр. за шумове, смрекову јагоду).

Ширина значења фитонима није сасвим уједначена, што је зависило од обухватности и прецизности онога пронађеног у наведеној литератури. 
Настојали смо да наведемо основне податке о биљној врсти која је фитонимом одређена (изглед, распрострањеност) и оне који се односе на њену лековитост, с обзиром на то да се ти подаци износе у самој лекаруши Косте Радовића. Они су, такође, након навођења контекста, укључени у одредницу.

Фитоними које смо наводили као синониме само су они који се у том својству у лекаруши јављају.

\section{4. Напомене о транскрипцији}

Лекаруша Косте Радовића настала је 1830. године и у великој мери је писана на народном језику, с тим да постоји низ језичких црта карактеристичних за славеносрпски тип књижевног језика, као што су, на пример, хибридне творевине са руским префиксом и српским наставком (внутрене), 3. л. јд. презента на -т (лечит, јест) (Бјелаковић 2003: 9). Уочљиво је и присуство два различита рукописа. На основу карактеристика језичког израза може се закључити да потичу из два различита временска периода. Први се приписује Кости Радовићу и везује се за 1830. годину, док се подаци о другом записивачу у лекаруши не проналазе - оно што се може рећи јесте да су његови записи настали након Радовићевих, тј. да је реч о млађем језичком изразу.

\section{1. Графијска анализа текста}

Графијска анализа текста исписаног првим рукописом указује на то да је он писан грађанском ћирилицом. Бележе се следеће графеме:

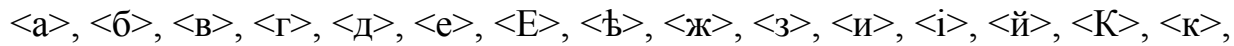
$\langle\mathrm{J}>,\langle\mathrm{M}\rangle,\langle\mathrm{M}\rangle,\langle\mathrm{N}\rangle,\langle\mathrm{H}\rangle,\langle\mathrm{o}\rangle,\langle\mathrm{\omega}\rangle,\langle\mathrm{\Pi}\rangle,\langle\mathrm{p}\rangle,\langle\mathrm{c}\rangle,\langle\mathrm{T}\rangle,\langle\mathrm{T}\rangle,\langle\mathrm{h}\rangle,\langle\mathrm{y}\rangle,\langle 8\rangle$,

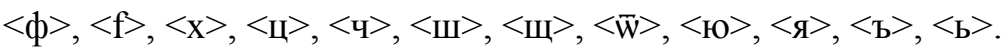

Текст написан другим рукописом на пољу графије доноси следеће

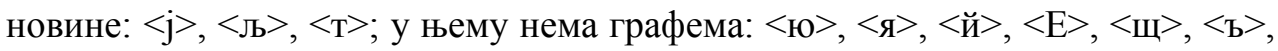
$<_{\mathrm{b}}>,<\omega>$; графема $<\overline{\mathrm{w}}>$ је присутна, али се јавља и као $<$ од $>$.

\section{2. Општа начела транскрипције}

Текст лекаруше транскрибован је савременом српском ћирилицом, тако да језик анализираног дела у потпуности одговара оригиналу. Транскрибовани су само фитоними, не цео текст записа, тако да се наведена 
решења транскрипције односе само на гласовне вредности наведених графема или графемских група које се јављају у оквиру фитонима. Приликом транскрипције посебна пажња је посвећена регистровању оних графема и графемских група које не представљају део инвентара савремене српске ћирилице или оних које су се у предстандардној епоси развоја српског књижевног језика могле употребљавати у различитим гласовним вредностима. Овом приликом наводе се транскрибована решења графема и графемских група које одговарају наведеном критеријуму.

- Графема <a> има фонетску вредност вокала /a/ и фонетску вредност /ja/ иза вокала: $<$ агать $>\rightarrow$ агат; <жалfia $>\rightarrow$ жалфија.

- Графема <e> има фонетску вредност вокала /е/ и фонетску вредност /jе/ иза вокала: <юргеть $>\rightarrow$ јургет; < р8евіна $>\rightarrow$ рујевина.

- $\quad$ рафема $<$ й $>$ има фонетску вредност сонанта $/ \mathrm{j} /:<$ йаб8ка $>\rightarrow$ јабука; $<$ йагоде $>\rightarrow$ јагоде.

- Графемска група <ни> има фонетску вредност $<$ ni $>$ и фонетску вредност $<$ ņi $>$ : <лешникъ $>\rightarrow$ лешник; <дренина $>\rightarrow$ дрењина.

- Графемска група <ли> има фонетску вредности $<\mathrm{li}>$ и фонетску вредност $<$ li $>$ : <листь $>\rightarrow$ лист; $<$ шлива $>\rightarrow$ шљива.

- $\quad$ ррафема $<\mathrm{i}>$ има фонетску вредност вокала /i/ и фонетску вредност сонанта $/ \mathrm{j} /:$ біберь $>\rightarrow$ бибер; <таміанъ $>\rightarrow$ тамјан.

- $\quad$ Графемска група $<$ iи $>$ којом се обележава наставак придева одређеног вида у мушком роду има фонетску вредност $/ \mathrm{ji} /:<$ дивіи кестенъ $>\rightarrow$ дивји кестен.

- $\quad$ ррафема $<$ я $>$ има фонетску вредност $/$ ја/: $<$ яаб8ковина $>\rightarrow$ јабуковина.

- Графемске групе <ля>, <ня> имају фонетске вредности /la/, /nga/: $<$ конопля $>\rightarrow$ конопља; $<$ вишня $>\rightarrow$ вишња.

- $\quad$ ррафема $<$ ю $>$ има фонетску вредност $/ \mathrm{ju} /:<$ юргетъ $>\rightarrow$ јургет.

- $\quad$ ррафемска група <лј>9 има фонетску вредност $/ 1 /:<$ куделја $>\rightarrow$ кудеља.

- $\quad$ Графема $<8>$ има фонетску вредност вокала /u/: $<68$ ндева $>\rightarrow$ бундева.

- Графема <ћ> има фонетску вредност /d/: <грожће $>\rightarrow$ грожђе; $<$ мироћија $>\rightarrow$ мирођија.

\footnotetext{
${ }^{9}$ Графемска група која је забележена само другим рукописом.
} 
- $\quad$ Графема <ч> има фонетску вредност /dž/: <поморанча > $\rightarrow$ поморанџа.

- Графемска група $<$ ep $>$ у позицији вокалног /r/ има фонетску вредност $/ \mathrm{r} /:<$ верба $>\rightarrow$ врба; <церни $>\rightarrow$ црни; $<$ тернина $>\rightarrow$ трњина.

- Графема $<_{\mathfrak{b}}>$ нема фонетску вредност, већ маркира крај речи: $<$ юргетъ $>\rightarrow$ јургет.

- Графема $<_{\mathbf{b}}>$ маркира палаталност гласа који јој претходи: <куколь $>$ $\rightarrow$ кукољ; <кель $>\rightarrow$ кељ.

Интервенције предузете приликом навођења текста записа односе се искључиво на ортографску раван - на растављено писање речи и интерпункцију:

- Кога мУчить каменъ или песакъ нека на дще ЕднУ или 2 смокве біберомь посУте Еде помоћи ћемУ. $\rightarrow$ Кога мучитъ каменъ, или песакъ, нека на дще едну или 2 смокве біберомъ посуте еде, помоћи ће му.

- Еднимъ яйцетомъ замесивщи, и растінУвщій толико колико стомахъ чіи посипатіи лютомъ ракіомъ комовицомъ и добро потрунити исиотомъ пакъ на стомахъ прівіти захладнбли стомахь угрбва и апетить дае и больтииУ утолБва. $\rightarrow$ Еднимъ яйцетомъ замесивши и растінУвшій толико колико стомахъ чіи, посипатіи лютомъ ракіомъ комовицомъ и добро потрунити исиотомъ, пакъ на стомахъ прівіти; захладнъли стомахъ угрњва, апетитъ дае и больтицу утольва.

\section{5. Речник}

A

агат камен / агат (Aloëxylon agallochuм) <агать каменъ>, <агатъ>. Смола алојевог дрвета. Алојево дрво је карактеристично за шире поднебље југоисточне Азије чија је смола, коју би почињало да лучи услед физичке озледе или напада паразитских организама, а која би се задржавала испод коре $и$ стврдњавала, била цееьена (Савић 2014: 17). Коришћена је за кађење и лечење (Симоновић 1959: 24). Агать камень [...]. Агатъ у прахъ да ст8че пакъ да смеша съ беланцомъ $\bar{G}$ яета на чело да прівіе (38a). У лекаруши Косте Радовића препоручује се за лечење људи: очних болести, велике болести, против подизања материце, за олакшавање порођаја; користи се као главни састојак смесе за облог и као средство за кађање.

Б

бела слачица(Sinapis alba) <бела слачица*>. Бела слачица се употребљава за дражење коже, као и 
за прављене сенфа, као зачин, особито у Северној и Западној Европи. Користи се њено зрно и семе (Туцаков 1997: 607). Бел8 слачиц8нов8 ист8ћи и у ново слатко віно метн8ти садржава сладость и брани ускісн8ти (55б). У лекаруши Косте Радовића препоручује се за лечење људи, враћање покретљивости удовима, и за спречавање вина да ускисне; користи се цела биљка или њено семе стучено у прах.

бибер (Piper, P. nigruм) <біберъ*>. Тропска биљка чији се зрнасти плод употребљава као зачин, који се исто тако назива. То је дуговечна повијуша која расте у тропској Азији, где се и гаји, као и у осталим тропским пределима. Бибер је својственог љутог и топлог укуса и ароматичног мириса (Туцаков 1997: 238-239). Кога м8чить каменъ или песакъ нека на дще Едн8 или 2 смокве біберомъ пос8те Еде помоћи ће м8 (54a). У лекаруши Косте Радовића препоручује се за лечење људи: камена и песка; користи се као храна.

боб (1. Phaseolus vulgaris, 2. Vicia faba) $<$ бобъ>. Једногодишьа зеласта, махунаста биљка из породице лепирњача, у употреби за људску и сточну храну. Достиже висину од 60 до 140 сантиметара. Пореклом је из Азије, а код нас се гаји попут пасуља $и$ грашка. У лековите сврхе користе се зелене махуне и цвет (Туцаков 1997: 241). Бобъ у сірћет8 скУвати и уютр8 уміті се чисти лице то (...) : люск8 скін8ті увече и чистомъ водомъ помешати чисти лице и светло прави (39б). У лекаруши Косте Радовића препоручује се за лечење људи: глувоће, отеклина, за негу лица; користи се као главни састојак облога, паре за инхалирање, течности за умивање.

боквица (Plamango, P. lanceolama, P. мајоr) <боквица*>. Зељьста биљка која се употребљава у народном лекарству (P1: 244). Код нас расте двадесетак врста боквице. У већини врста боквице лишће се развија у облику розете у дну стабљике која није граната и нема лишћа, него се завршава збијеном цвашћу од ситних цветова. Најраспрострањеније су тзв. широколиста боквица (P. мајог), усколиста боквица (P. lanceolama) $и$ средња боквица (P. медіа), и користе се као лек у народу. У лековите сврхе користе се свеж и сув лист, ређе цела биљка и корен (Туцаков 1997: 242-243). А противъ крвавогъ отока истино лькарство да се у сірћет8 раци ск8ваю и люске $\bar{G}$ нихъ сасма ист8чене у прахъ пакъ тога праха давати уютр8 и увече по 1. f квінтлекъ у вр8ћ8 црвен8 він8 или $\omega$ боквице воде (50а). У лекаруши Косте Радовића препоручује се за лечење крвавог отока код људи; користи се као састојак лековитог напитка. (=буква (трава), ${ }^{1}$ подорожна буквица).

${ }^{1}$ Не може се са сигурношћу тврдити, али се може претпоставити из више разлога - као прво сасвим је јасно да није реч о букви као врсти дрвета, већ као о врсти ниске зељасте биљке, јер се наглашава да је реч о трави, као друго, буква као трава наводи се у посебном запису насловљеном буква, што упућује да је реч о две различите биљне врсте. С тим у вези, назив боквица не налази се у наслову ниједног записа, него у његовом тексту, под сирће. Њено 
бор / боровина (Pinus, P. halepensis, $P$. nigra, $P$. pinea, $P$. silvesmris $)<б о р ь *>$, $<$ боровина>. Врста четинара чији се млади пупољии користе у лековите cврхе (Туцаков 1997: 225-226). Боровина [...]. Борова кора ист8чена у прахъ добра Е на свак8 ран8 и краст8 такоћеръ и наиждегъ (38а). У лекаруши Косте Радовића препоручује се за лечење људи: рана и краста; користи се као прах.

бреза (Bemula, B. pubescens, $B$. verrucosa) <бреза>. Врста листопадног белогоричног дрвета беле коре. Реч је о витким дрветима с белом кором $и$ витким, танким гранчицама. $У$ лековите сврхе користе се лист, кора и свеж сок добијен у пролеће(Туцаков 1997: 250). Бреза [...] найвише ране лечи кад томь водомь испіраю (38а). У лекаруши Косте Радовића препоручује се за лечење људи: негу лица и испирање рана; користи се као течност за испирање и умивање.

бресква / бресковина (Prunus persica) $<$ бресква $>$, <бресковина*>. Врста воћке и юен плод (Р1: 271). Бресква [...]. А смола $\overline{\mathrm{GO}}$ бресковине омочена у води или вин8 чисти перси (...) жиле и каменъ разбия кад се піе (38б). У лекаруши Косте Радовића препоручује ce за лечење људи: камена, очију, ушију, чишћење груди (плућа), спречавање опијања од вина; користи се

именовање у тексту записа, а да се не налази у наслову, могло би значити да је та биљна врста већ раније обрађена. Све то наводи да се буква трава може поистоветити са боквицом, на шта упућује и сличност њихових назива. језгро њене коштице, уље исцеђено из коштица, смола из дрвета брескве.

брестовина (Uulмus, U. campesmris, $U$. scabra)<брестовина >. Bpcma листопадног белогоричног дрвета (P1: 271). Снажно дрво које расте до 35 метара висине. 3 а лековте сврхе употребљава се унутрашња и средња кора са грана старости једне до две године (Туцаков 1997: 251). Брестовина [...]. $\overline{\mathrm{GD}}$ брестовине Езеро добро прок8вати 8 истой води омочить крп8 превіяти на иждегъ но найпре помицати да пріоне на ран8 прекіа лекъ есть (40а). у лекаруши Косте Радовића препоручује се за лечење рана код људи; користи се као састојак за справљање лековитог облога.

буква (Fagus, F. silvamica) <б8ква> Врста листопадног дрвета, расте до 35 метара висине. У лековите сврхе користе се њен плод и кора (Туцаков 1997: 252). Буква [...]. Каходи се у старои б8квіи и растовини вода у ш8плини коя есть на свако вн8тренно добра и человък8 и скот8 т8 полезна (38б). У лекаруши Косте Радовића препоручује се за лечење људи (оток вилице, зубобоље, унутрашњих органа) и домаћих животиња (унутрашњих органа); користи се као храна и напитак.

буква [трава]<б8ква>. Зељаста биљка, врста траве (Радовић 1830: 39б, 40а).Буква[...]. Прахь $\bar{G}$ неке траве на рану добарь (39б, 40а). У лекаруши Косте Радовића препоручује се за лечење људи: против деловања отрова, за заустављање повраћања, за лечење цревних болести, рана, очију, ушију; користи се као састојак лековитог напитка, као прах и сок добијен 
цеђењем. Види боквица. (= боквица, подорожна буквица).

бундева (Cucurbima, C. мelopepo, C. ovifera, C. реро) <б8ндева*>. Врста тикве која се употребљава за исхрану људи и стоке. Једногодишња зељаста биљка са пузавим, ребрастим, бодљикавим стабљикама дугачким до 10 метара. Листови су огромни, срияолики, плитко петоделни, по ободу назубљени. Цветови су жути, мушки су крупнији од женских. Плод је огромна округла боба, тешка и преко 10 килограма, споља бело-сивкаста, а на пресеку нараниаста, месната и сочна, у шупљини су семенке. Цвета током јула и августа, а сазрева током септембра и октобра. Пореклом је из тропске Америке. У лековите сврхе користе се зрео плод и семе (Туцаков 1997: 252). Тиква и б8ндеве кора у пепел8 спальна естъ лековито тим пепеломъ гнил8 ран8 насипати (58a). У лекаруши Косте Радовића препоручује се за лечење људи: рана и инфицираних рана; користи се као прах.

\section{B}

винова лоза (Vimis vinifera) $<$ винова лоза>. Биљка која се гаји ради грожђа. У лековите сврхе користе се лист и плод (Туцаков 1997: 275-276). Винова лоза [...]. $\bar{G}$ листа винова вода исцећена добро пити тому кои врло блюе (40б, 41a). У лекаруши Косте Радовића препоручује се за лечење људи: камена, болесних очију, желуца, температуре, болести главе, претераног повраћања, за побољшање апетита и одржавање чистоће тела; користи се вода од винове лозе, њен пепео, лист, употребљава се као храна. (=грожђе). вишња (Prunus cerasus) ${ }^{2}<$ вишня >. Дрво $u$ плод воћке сличне трешњи. У лековите сврхе користе се плод, семенке и петељке (Туцаков 1997: 277). Вишня и трешня раћаю смол8 коя 8 сирћет8 ск8вана ш8г8 лечи и красте на тъл8 (40б). У лекаруши Косте Радовића препоручује се за лечење људи: шуге и краста по телу; користи се смола вишњевог дрвета припремљена као течност за испирање.

врба (Salix) <верба>. Листопадно дрво или ииб из истоимене породице која расте крај воде и на влажном тлу (Р1: 428). Верба [...]. Лишће от нь истучено у ладной води коя жена често піе не роди (40б). У лекаруши Косте Радовића препоручује се за лечење људи: брадавица и жуљева, против зачећа, за чишћење лица и очију; користи се њено лишће и вода од брезе, употребљава се као напитак и облог.

\section{$\Gamma$}

горки бадем (Prunus coммunis aмara) $<$ горки бадемъ >. Дрво коштунава плода које се гаји у топлијим крајевима. Расте до 5 метара висине, листови су му дугуљасти, ииљасти, по рубу оштро тестерасти, ияетови ружичасте боје, а плод је дугуљаста коштунииа у којој се налази једна, ређе две, семенке. У

2 Код Симоновића за народни назив вишња, поред латинског Prunus cerasus наводи се и Phaseolus coccineus. Међутим, други латински назив означава шарени пасуљ, а из записа у лекаруши јасно је да је реч о дрвету, јер оно лучи смолу, а наводи се заједно са трешњом, која је вишњи слична, а такође је дрво. 
семену горког бадема има хетерозида амигдалозида, због чега је оно горко, отровно и лековито. Пореклом је из Мале Азије и Месопотамије, одакле се раширио свуда око Средоземног мора. У лековите сврхе користи се юегово семе и уље добијено юеговим иеђењем (Туцаков 1997: 221). Горки бадемъ у Ел8 бодри Ес8 протів8 fлегме у гр8ди исчисти стомахъ и даю санъ (39a). У лекаруши Косте Радовића препоручује се за лечење људи: флегме у грудима и стомаку, песка; користи се као састојак у јелу и као састојак за справљање лековитог напитка.

горушица <гор8шица*>. Једногодишња или двогодишња зељаста биљка, висока до 80 им. Расте свуда, а највише као бујан коров у јарим усевима. Њено семе користи се за лечење и исхрану (Туцаков 1997: 297). Р8ке беле кой хоће да има не $\bar{G}$ ист8чена бадема и гор8шице начини брашно тимъ и сап8номъ уЕдно испере (55a). У лекаруши Косте Радовића препоручује се за лечење људи: за бељење коже руку и поправљања слуха; користи се њено семе стучено у прах. Види слачица. (=слачица).

григот каламус ароматис / григот (Acorus calamus) <григоть calaмus aroматіs>, <гріготъ>. Иђирот, дуговечна зељаста биљка с врло развијеним и разгранатим ризомима, који су на доњој страни обрасли многобројним жиличастим корењем, а од горе правим, зеленим, сабљастим, до једног метра дугачким и до 3 сантиметра широким, листовима. Стабљика је при дну ирвенкаста, а на врху се завршава збијеним иветним жућкасто-зеленим клипом окренутим у страну. Цвета током јуна и јула. Плод је дугуљаста црвена бобица. Цела биљка пријатно мирише. Pacmе у мноштву по нашим блатима и мочварама свуда поред Дунава, Тисе, Саве и других река. У лековите сврхе користи се његов ризом (Туцаков 1997: 351). Григотъ calaмus aromatis [...]. Изрезавшіи гріготъ на колце ситно и у стакл8 положивши $\overline{\mathrm{G}}$ винске киселице ракіомъ нас8ти, после на вр8ћой ф8р8ни или на с8нц8 дещилирати на неколико дней, свако ютро оте ракіе пити добро ради стомаха и крьпленіе (43a). У лекаруши Косте Радовића препоручује се за лечење људи: болести стомака и за побољшање општег стања организма; користи се његов корен као састојак лековитог напитка.

грожђе <гроздіе>, <грожће*>. Плод винове лозе, често од великог броја зрна на једној петељии (Р1: 574). Гроздіе [...]. Грожћа мало с8вогь нашити са биберомъ и у 8сти држати валя тітечли $\bar{G}$ главе мокрот8 (41б). У лекаруши Косте Радовића препоручује се за лечење људи: болести главе; користи се као храна. Види винова лоза. (=винова лоза).

Д

дивји кестен (Aeculus, Ae. hippocasmanuм) <дивіи кестенъ >. Дивљи кестен је високо листопадно дрво које се као украс сади по парковима $u$ дрворедима. Врло је корисно и лепо дрво. У лековите сврхе користи се његово семе и кора, ређе ивет (Туцаков 1997: 306). Дівіи кестенъ ФЈс8шен и добро сатрвенъ хоће гл8хот8 излечити (43a). У лекаруши Косте Радовића препоручује се за лечење глувоће код људи; користи се његов плод. 
диња (Сисимis меlo) <диня>. Једногодишьа зељаста биљка са дугачким полеглим врежама. Гаји се у великом броју варијетета као укусно слатко воће. У лековите сврхе користе се плод, семе и корен (Туцаков 1997: 317). Диня [...] бива слаћа и лепша кад ce найпре семе мало [...] (42a). У лекаруши Косте Радовића не наводе се њена лековита својства, него се даје савет за припрему диње, тј. за побољшање њене слаткоће.

дрен / дрењине (Cornus мas) <дренъ>, <дренине*>. Грм или ниско дрво, високо од 5 до 8 метара. Гране су му длакаве, зелекасте или сивкасте. Листови су наспрамни, одоздо светлији, елиптични и по ободу цели. Цветови су жути, јављају се рано, пре листања, већ $у$ марту, сакупљени у ититасте кичице, правилни су и четворочлани. Расте свуда, а највите по сунчаним, каменитим странама светлих листопадних иума заједно са другим грмљем и иибљем. У лековите сврхе користе се свежи и осушени плодови, ређе кора (Туцаков 1997: 321). Дрень [...]. 1. Лишће $\bar{G}$ дрена или замеци ньга у він8 к8вати или семе особно свак8 т8к8ћ8 ран8 прівіена с8ше и лече добро. 2. О дренина може се віно направити кое лекъ протіво вн8трень разлабливости, или тога напредъ или натрагъ [...] (41б). У лекаруши Косте Радовића препоручује се за лечење људи: рана и унутрашње раслабљености, употребљава се вино направљено од дрена, лишће, замеци и семе као облог.

дуд (Morus) <дудъ>. Листопадно дрво и његов плод (Р1: 802). Разликују се ирни (M. nigra) и бели дуд (M. alba). Користе се за лечење, плод и лист, и плод за исхрану људи и домаћих животиња (Туцаков 1997: 322-323). Дудь [...]. Лишће $\bar{G}$ ньга истучено [...] (42а). У лекаруши Косте Радовића препоручује се за лечење људи: зубне болести и температуре, грознице; користи се његово лишће, употребљава се за инхалирање или испирање.

\section{Ж}

жалфија (Salvia, S. officinalis) <жалfia>.Жалфија је дуговечан, разгранат грм висок од 50 до 90 сантиметара. Стабљика је дрвенаста, вишегодишьа и четвороугласта. Листови су сребрноозелени због обиља длака. Цветови су плаво-љубичасти, понекад ружичасто-беласти, изразито двоуснати и налазе се удружени $у$ класасте пршьенове на врховима стабљика и огранака. Цела биљка је врло ароматичног $и$ својственог мириса. У лековите сврхе користи се нен лист (Туцаков 1997: 333, 335). Nемецкіи сулfеръ или на србскіи жалfia зове се кое весма полезне на ране када изић8 по тьл8 б8б8лице и начин8 се ране валя жалfію изсећи и у п8терь попржити то естъ да се истопи п8теръ, пакъ после када се Флади мазати ран8 врло лековито естъ (67б). У лекаруши Косте Радовића препоручује се за лечење људи: рана и бубуљица; користи се као састојак за справљање лековите масти.

жир <жіръ>. Плод храста (Р2: 40). Такоћеръ жіръ и р8жіца у води к8вана узима се противъ крвава плюваня (52а). У лекаруши Косте Радовића препоручује се за лечење људи: против крвавог пљувања. Види храст. (= храст). 
3

змирна / смирна (Соммірhora abyssinica, C. schimperi, Smyrax benzoin) <змірна>, <смірна*>. Измирна је балсамична смола добијена из засеченог стабла разних врста Smyrax (Smyracaceae), које pacmy дивље, а местимично се и гаје у индомалајском подручју (Туцаков 1997: 353). 1. Змірна [...]. Такоћерь добро е и за смрадлива д8ха уста мало змірне држати и то піти (42б). 2. С таміаномъ и смірномъ и шафраномъ помьшавшіи да се жена $\bar{G}$ дол8 помаже Ей на почетку Ечмене и пороћеня (43б). У лекаруши Косте Радовића препоручује се за лечење људи: одржавање хигијене усне дупље, олакшавање порођаја, промуклости и кашља, поквареног стомака, одржавање здравља зуба и десни, лечење рана, поготово на глави; користи се као састојак лековитог напитка, лековите масти и течности за испирање, и као прах.

зова (Saмbucus nigra) <зова $>^{3}$. Зова је грм или мање дрво високо до 5 метара. Она врло рано олиста. Гране су јој испуњене белом сржи. Има наспрамне, непарно перасте листове. Цветови су ситни, млечнобели, јаког мириса, удружени у врло крупне рачвасте цвасти сличне шттиу. Плодови су ситне, зељасте, а кад сазру, тамнољуичасте бобице с ирвеномодрим соком. Цвета од маја до јула. Расте свуда, највише по влажним $u$ запуштеним местима, по насељима $и$ око ьих, по ободу шума и шумским просецима. У лековите сврхе користи се юен ивет (Туцаков 1997: 346-347). [...] зова дална зелена кора [...] (72a). У

\footnotetext{
${ }^{3}$ Форма забележена другим рукописом.
}

лекаруши Косте Радовића препоручује се за лечење рана код људи; користи се њена зелена кора.

\section{И}

исиот (Zingiber officinale) <исиоть>. Бумбир, вишегодишьа биљка, пореклом је из тропске Азије, користи се у великој мери као зачин. У лековите сврхе користи се юегов ризом (Туцаков

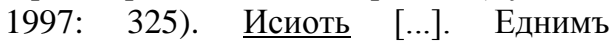
яйцетомъ замесивши и растін8вшій толико колико стомахъ чіи посипатіи лютомъ ракіомъ комовицомъ и добро потрунити исиотомъ, пакъ на стомахъ прівіти, захладньли стомахъ угрђва и апетить дае и больтиц8 утольва (42б). У лекаруши Косте Радовића препоручује се за лечење болести стомака и враћање апетита; користи се као прах.

\section{$\mathbf{J}$}

јабука / јабуковина (Malus puмila) <йаб8ка>, <яб8ковина*>. Врста воћке из породиче ружа са много подврста; њен плод. Воћка висока до 10 метара. Гаје се многе сорте чији састав није исти: кисела, опора, слатка итд. У лековите сврхе користи се њен плод (Туцаков 1997: 360).1. Йаб8ка [...]. Ако га сан(...)iе пребияю нека метне у яб8к8 т8чена таміяна, пакъ испеквшіи прівіе хоће ома помоћи. 2. Лишће зелено $\overline{\mathrm{G}}$ яб8ковине ист8чено или 8 вод8 исцећено, употребити на Фгнђвити отоке положити $(60 \mathrm{a}, 606)$. У лекаруши Косте Радовића препоручује се за лечење људи: спречава дејство отрова, тера глисте, за лечење отока; користи се лишће и плод, употребљава се као облог.

јагода (Fragaria, F. vesca) <йагода*>. Ниска зељаста биљка из породице ружа c округлим меснатим плодом ирвене 
боје (Р2: 554). Йагоде [...] црвене летнь $\widetilde{\mathrm{G}}$ нихь исцећена вода у свое време [...] (60б). У лекаруши Косте Радовића препоручује се за лечење људи: болести зуба и одржавање хигијене усне дупље, отоке грла; користи се сок (вода) добијен цеђењем плодова.

јасеново дрво (Fraxinus, F. excelsior, $F$. ornus) <ясеново дрво*>. Врста шумског дрвета из породице маслина, са више подврста, пераста лишћа (P2: 568). Ясеновимъ дрветомъ почеши се по нос8 и ст8деномъ водомъ уми образъ и из кости стране иде иде у оной р8пи држи дрво ясеново (63a). У лекаруши Косте Радовића препоручује се за заустављање крви из носа код људи; користи се јасеново дрво.

јургет (Lagenaria vulgaris) <юургетъ>. Дугуљаста тиквица, користи се за исхрану (Симоновић 1959: 259). Юргеть [...]. $\widehat{\mathrm{G}}$ ньгове коре пепео добарь на [...] (60a). У лекаруши Косте Радовића препоручује се за лечење инфицираних рана код људи; користи се његова кора као прах.

\section{$\mathbf{K}$}

кајсија (Prunus arмeniaca) <кайсія>. Дрво из породиие ружа жуто-ирвеног плода с великом коштицом; плод тог дрвета (Р2: 630). Кайсія [...] зейтинь есть добарь [...] (43а). У лекаруши Косте Радовића препоручује се за лечење огњевитих отока код људи; користи се уље добијено цеђењем коштица.

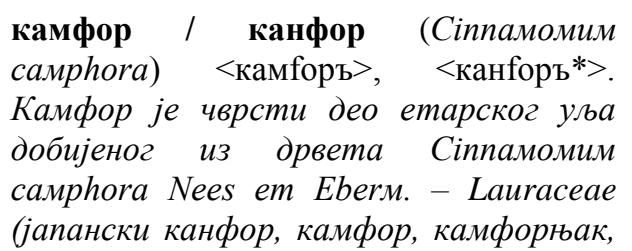

камфорово дрво) или синтетски од пинена (борово, терпентинско уље). То су кристални комади својственог мириса. Брзо ветри, па се мора херметички запаковати и чувати на хладном месту (Туцаков 1997: 371). 1. Камfopь [...] помагаеть з8бма да не болять (43a). 2. Да 8зме морасть папирь и да намаже са белимъ плайвазомъ у коим8 канfора има пакъ папирь да избоцка потомъ да привіе хоће се помоћи (62a). У лекаруши Косте Радовића препоручује се за лечење људи: зубобоље, осипа по телу, слабљење похоте; користи се као састојак течности за испирање, као облог, препоручује се удисање његовог мириса.

карамфил (Dianmhus, D.caryophyllus, Eugenia caryophyllama) <карамfилъ>. Украсна биљка са иветовима разних боја. Баштенски или вртни каранфил и многе дивље врсте каранфила користе се у народној медицини. У лековите сврхе користи се његов ивет (Туцаков 1997: 373). Карамfиль [...] есть врло лековить (44a). У лекаруши Косте Радовића препоручује се за лечење људи: оштри вид, против несвестице; користи се као састојак лековите течности за помазивање и као храна, тзв. маџун.

кељ (Brassica oleracea acephala, B. oleracea sabauda) <кель>. Врста куnуса која има смежурано лишће и нешто мекше главице (Р2: 697). Кель [...]. $\overline{\mathrm{GJ}}$ кела и к8п8са и пальна кореня пепель начинънъ и $\overline{\mathrm{G}}$ нъга цећъ к8ванъ 8дивително естъ добро противъ хладногъ огня кад се тимъ пере (43б, 44a). У лекаруши Косте Радовића препоручује се за лечење људи: шуге, рана, глувоће, модрица и подлива, 
хладне грознице; користи се његово лишће, сок добијен цеђењем, вода у којој се кувао, пепео као облог, састојак течности за испирање, састојак средства за купање.

кестен (Casmanea samiva) ${ }^{4}<$ кестенъ>. Врста листопадног дрвета из породице букава са много подврста; плод тог дрвета (Р2: 701). Печен кестенъ кад се ист8че пакъ са медомъ и солю на ран8 бесна пса пріложіа врло помагаетъ (43a). У лекаруши Косте Радовића препоручује се за лечење људи: рана од уједа бесног пса, крвавог кашља и за регулисање крвног тока и менструације; користи се његов плод као састојак лековите масти, облога, напитка.

конопља (Cannabis samiva) <конопля>. Биљка из породице конопљика која се употребљава као сировина за прављење грубљих тканина и ужади (Р2: 824). У лековите сврхе користи се ьено семе (Туцаков 1997: 402). Конопля [...] семе $\overline{\mathrm{G}}$ нь кад се лепо отаре [...] (44a). У лекаруши Косте Радовића препоручује се за лечење људи: болести ушију и болести утробе; користи се њено семе, које се употребљава као састојак лековитог напитка (млеко из њега исцеђено) и као облог. (= кудеља).

копар (Anemhuм graveolens) ${ }^{5}<$ копаръ >. Биљка из породице ититара која се

${ }^{4}$ Код Симоновића за кестен је наведен и латински назив Solanum tuberosum, што је кромпир. На основу записа у лекаруши може се закључити да је реч о кестену као плоду кестена дрвета.

5 У лекаруши Косте Радовића копар се поистовећује са мирођијом, тако да се гаји по вртовима и употребљава у сировом стағу као зачин у јелу, мирођија (Р2: 843). Свима добро позната зачинска мирисна биљка веома распрострањена. $У$ лековите сврхе употребљава се зрео плод, ређе врхови гранчииа у ивету (Туцаков 1997: 483). Копаръ [...] (42б). Млогу крв зауставити од копра (мироћије) семе куван теи (72б). У лекаруши Косте Радовића препоручује се за лечење људи: желуца, материце, унутрашњих болести и камена, за заустављање крви; користи се као састојак лековитог напитка и чај скуван од његовог семена. (= мирођија).

коприва (Celmis ausmralis, Urmica, U. $\underline{\text { urens })}<$ копріва>, <коприва>. Коровна биљка са иглицама на лишћу и стабљици које надражују кожу кад се дотакну. У лековите сврхе користе се врхови гранчица са лишћем, сам лист, иела надземна биљка у извету или само корен (Туцаков 1997: 405). Копріва[...]. Коренъ $\bar{G}$ велике коприве 8 мед8 и він8 к8ванъ Еденъ лечи гладанъ и с8хъ кашаль Еръ отвара жигериц8 $\overline{\mathrm{GJ}}$ дшанеи $(446,45 a)$. У лекаруши Косте Радовића препоручује се за лечење људи: бола у боковима, унутрашњих рана, кашља, тескобе у грудима, болести уринарног тракта; користи се њен корен, цвет, лишће и семе, употребљава се као састојак лековитог напитка и као храна.

на основу њеног латинског назива (Anethum graveolens) може уже одредити и латински назив за копар, односно од два која се код Симоновића наводе (Anethum graveolens, Foeniculum vulgare) изабрати један с којим се у овом случају подудара (Anethum graveolens). 
кора <кора>. Спољашњи део дрвета који се лако може одвојити (Р2: 848). Махъ или кора $\overline{\mathrm{G}}$ растова дрвета за8ставля срдоболю у він8 к8ванъ (47a).

корен <коренъ*>. Подземни део биљке помоћу ког се она учврићује и ирпи из земље воду и хранљиве материје (Р2: 852). Ако свако ютро наште срце Едеш помалоъ тога корена утолява болестъ у стомах8 (43a).

крин или лен (Phorмiuм menax) <кринъ или ленъ >, <крінь>. Ланени крин,биљка која достиже висину од два до три метра. Цвета од краја пролећа до почетка лета. Највите јој одговара влажно и мокро земьиште. Користи се за израду тканина (http://www.pfaf.org/ user/plant.aspx? ?aтinnaмe=

Phorмiuм+теnax, 22.09.2016.). Кринъ или ленъ [...]. То кріновъ цветъ у лютой ракіи са камfоромъ дестілірати добарь естъ прівіяти на ғришк8 ран8 не да се позледити и тако скоро лечитъ (42б). У лекаруши Косте Радовића препоручује се за лечење људи: рана, главобоље, ублажавање бола; користи се његов цвет и лишће, употребљава се као облог.

крушка (Pirus, $\quad$ P. coммипis) <кр8шка*>. Листопадна дрвенаста биљка из породице ружа с јестивим плодовима, који имају облик округластог конуса; плод тог дрвета (Р3: 100). Изъ кр8шке или изъ др8ге воћке б8б8 коя горе иде са два прста уfатити и згньчити у Едн8 кашік8 са водомъ или са чимъ драго попити (68а). У лекаруши Косте Радовића овој биљци се директно не преписује лековито дејство, већ се она јавља као станиште буба које се препоручују за лечење бруха код људи. кудеља (Cannabis samiva) <куделја*> ${ }^{6}$. Биљка из породице коприва из чије се стабљике добија влакно за предење, а из семена биљно уље (Р3: 111). Куделу окади на ситно утучен шећер и зрви восак и онако вруће мети на севатину (68б). У лекаруши Косте Радовића препоручује се за лечење људи: тзв. севатине и трипла; користи се њено семе као састојак лековитог напитка и као облог. Види конопља. (= конопља).

кукољ (Agrosmемма gimhago, Vicia samiva) <куколь>. Биљка из породице каранфила с плаво-ирвенкастим иветовима $и$ отровним семенкама, расте као коров по њивама и ливадама (P3: 117). Отровна биљка која се не користи у научној медицини (Туцаков 1997: 419). Куколь [...]. С таміаномъ и смірномъ и шафраномъ помъшавшіи да се жена $\overline{G O}$ дол8 помаже [...] (43б). У лекаруши Косте Радовића препоручује ce за олакшавање порођаја жена; користи се као састојак лековите масти.

кукута (Сопіим масиатим) <к8к8та> Једна од наших најпознатијих $u$ најобичнијих отровних и смрдљивих корова која расте по насељима и око юих, по запуштеним и неуредним местима. Веома је распрострањена. Стабљика је висока до 2,5 метара, снажна и разграната, уздуж пругаста u посута риђим или мркочрвеним пегама; лишће је меко, троугласто, исиепано; иветови су ситни, неугледни, бели и скупьени у штитове; плод је јајаст или округласт, сиво-зелене боје. У лековите сврхе користе се њен плод и лист (Туцаков 1997: 421-422). К8к8та[...] хлади сваке гореће отоке [...]

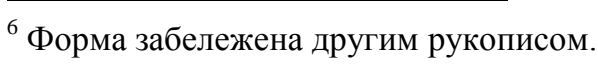


(44б). У лекаруши Косте Радовића препоручује се за лечење људи: заустављање раста груди код жена и прекида лактације, за хлађење горећих отока и ублажавање бола; користи се као облог.

купус (Brassica, B. oleracea capimama) ${ }^{7}$

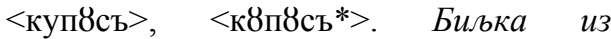
породице крсташица са много подврста (P3: 132). Заузима значајно место у нашој исхрани, нарочито зими кад нема свеже, зелене хране; садржи доста $C$ витамина. У лековите сврхе користи се юегов лист и сок добијен юеговим цеђењем (Туцаков 1997: 424). Куп8сь [...]. $\bar{G}$ кела и к8п8са и пальна кореня пепель начиньнъ и $\bar{G}$ нъга цећъ к8ванъ 8дивително есть добро противъ хладногъ огня кад се тимъ пере (43б). У лекаруши Косте Радовића препоручује се за лечење људи: хладног огња и за добијање тежине; користи се као састојак средства за прање и као храна.

\section{Л}

лан (Linuм, L. usimamissimuм) <ланъ>. Лан је гајена једногодишња зељаста биљка, висока 50-80 сантиметара. Стабљика је танка, ваљкаста и слабо обрасла ситним дугуљастим листићима; на горњем делу је мало разграната, а на врховима огранака има по један ситан, врло нежан цвет

${ }^{7}$ Код Симоновића наводи се неколико латинских назива за куnус (Brassica, B. olearacea acephala, B. oleracea capitata, B. oleracea sabauda), међутим, када се издвоје латински називи за кељ, који припада истом роду, остаје један латински назив за куnyc (B. oleracea capitata). плаве боје. Плод је округласта чаура са десет семенки. $У$ лековите сврхе користи се његово семе (Туцаков 1997: 427-428). Лань [...] сваки отокь болећи прівіено помаже (45a). У лекаруши Косте Радовића препоручује се за лечење људи: несвестице, срдобоље, температуре, плућних болести, тзв. санчие, за заустављање крви, за ублажавање бола отока; користи се његово семе као храна, облог и састојак лековитог напитка.

левендула (Lavandula, L. officinalis) <левенд8ла>. Лаванда је дуговечан, разгранат грмић, висок 40-60 сантиметара; има много усправних изданака густо обраслих уским, рузмарину сличним, листићима. Цела биљка је сива од обиља длака. Врхови грана обрасли су ситним плавим иветовима удруженим у ивасти сличне класју. Расте дивља на сувим, топлим, мршавим и кршевитим падинама западног дела Медитерана. Такође се и гаји. У лековите сврхе користи се юен цвет (Туцаков 1997: 426). Левенд8ла[...]. Nека 8зме левенд8ла сирћета $1 / 2$ холбе и к том8 да узме [...] (47a). У лекаруши Косте Радовића препоручује се за лечење људи: главобоље, болести зуби и мозга, за побољшање раста косе; користи се сирће направљено од њеног цвета, које се употребљава за прављење облога.

лешник (Corylus avellana) <лешникъ>. Плод леске, ииба и грма из породиие бреза (P3: 193; 200). Густ ииб глатке коре и савитьивих грана, висок до 5 метара. Листови су крупни, овални, на врху шиљати, на основи срцасто усечени, одоздо длакави и по ободу двоструко тестерасто усечени. Мушки иветови су жуте ресе које се јављају 
већ у септембру, а женски у јануару или фебруару у збијеној ивасти која изгледа као пупољак. Плод је орашиияа доюим делом умотана у зелени чупав овој. Оплодница је чврста, дрвенаста и у њој се налази укусна семенка која се користи у исхрани. У лековите сврхе користе се млади лист, кора, семе и уље (Туцаков 1997: 433-434). Т8ченъ лешникъ са ситнимъ с8вимъ грожћемъ поквареной жигерици (45a). У лекаруши Косте Радовића препоручује се за лечење јетре код људи.

лист / лишће <листь*>, <лишће*> ${ }^{8}$. Један од главних органа биљака, бочни израштај на гранчицама, ређе на стаблу и грани, пљоснате површине, обично зелене боје, различитог облика, помоћу кога се одвија транспираџија биљке (Р3: 214). 1. $\overline{\mathrm{G}}$ листа винова вода исцећена добро пити тому кои врло блюе (41a). 2. 77 лишћа од пасуља истући и соfт исцедити и да пије пре грознице, а лук да се ольушти на пираје, да се посоли, да стоји 6 сати и на дену и на другу руку и пупак превије (71б).

лук бели (Alliuм samivuм) <л8къ бели>, $<$ бели л8к*>. Зељьста биљка из породице љиљана са подземним стаблом облика луковице која је у великој употреби у исхрани и народној медицини (Р3: 243). Л8къ бели [...]. Бела л8ка метн8ти у напитакъ бела віна пакъ ск8вавшіи оцедити и попити тера каменъ, вод8 и женамъ и женамъ зауставля месечин8 (46б). У лекаруши Косте Радовића препоручује се за лечење људи: куге, камена, за регулисање менструације, за одржавање хигије, тј. сузбијање паразита; користи

${ }^{8}$ Форма забележена другим рукописом. се као састојак лековитог напитка, лековите масти и течности за прање, и као храна.

лук црни (Alliuм сера) <л8къ церни>. Зељаста биљка из породице ьиљана са подземним стаблом облика луковице која је у великој употреби у исхрани (Р3: 243). У народној медицини лук се вековима успешно употребљава за лечење многих болести споља $u$ изнутра, као профилактичко средство против заразних болести, свакодневна храна и зачин (Туцаков 1997: 448). Л8къ церни [...] коме с8 кашліомь закварене грд8и есть врло добро (45б). У лекаруши Косте Радовића препоручује се за лечење људи: кашља, куге, болести очију, пега, за побољшање раста косе, слуха, растерује шум из главе, за заустављање крварења из носа, за регулисање уринирања код мале деце; користи се као храна, као облог, као састојак лековите масти и течности за укапавање и за прање.

\section{M}

мак (Papaver, P. soмniferuм) $<$ макъ $>$. Мак је једна од најстаријих културних биљака која се гаји као хранљива, лековита, индустријска и украсна биљка. Цењен је због опијума који се од њега добија (Туцаков 1997: 456-457). Макь [...] мета на чело и на слепе очи (47б). У лекаруши Косте Радовића препоручује се за умиривање нервозних и ментално оболелих људи; користи се његово семе и стабљика као облог.

Max (Lobaria (=Smicma) pulmonacea) $<$ махъ>. Лишај плућњак. Овај крупан лишај развија се у облику крупних, жилавих, смеђих, неправилних крпа прилепьених на старим стаблима шумског дрвећа, на пањевима и 
стенама (Туцаков 1997: 443). Махъ или кора $\bar{G}$ растова дрвета за8ставля срдоболю у він8 к8ванъ (47a). У лекаруши Косте Радовића препоручује се за лечење људи: срдобоље, болести грла и зуба; користи се као састојак лековитог напитка и течности за испирање грла и усне дупље.

мирођија (Anетhим graveolens) <міроћія>, <мироћія>, <мироћија*>? Мирисна биљка из породие ититара која се употребљава као зачин, копар (P3: 381). Свима добро позната зачинска мирисна биљка веома распрострањена. $У$ лековите сврхе употребљава се зрео плод, ређе врхови гранчииа у ивету (Туцаков 1997: 483). 1. Міроћія [...] ветрове жел8дца (426, 43a). 2. 1 мироћия: у зетин8 тинщовата и са тимъ 8сам дана превіяти (68a). 3. Млогу крв зауставити од копра (мироћије) семе куван теи (72б). У лекаруши Косте Радовића препоручује се за лечење људи: бруха, желуца, материце и за заустављање крви; користи се као састојак лековитог напитка, чај скуван од њеног семена и као облог. Види копар. (= копар).

мушкатунус (Myrismica fragrans) $<$ м8шкатн8съ>. Мускатово дрво, које расте на Молучким острвима; има орашаст плод који служи као зачин и у апотекарству за справљање мирисних есенција (P4: 183). Конзумиран у већим количинама има отровно дејство (Туцаков 1997: 491). [...] 3 м8шкатн8сь 2 лота [...] (60б). У лекаруши Косте Радовића препоручује се за лечење људи: несвестице, костобоље,

\footnotetext{
${ }^{9}$ Форма забележена другим рукописом.
}

срдобоље; користи се као састојак лековитог напитка и као лековита маст. мушмула (Mespilus germanica) $<$ м8шм8ла>. Грм или дрво из породиче ружа и његго плод (Р3: 477). Њен плод се користи за исхрану и за израду сирупа (Туцаков 1997: 526). М8шм8ла [...] великомь силомь тера камень (47a). У лекаруши Косте Радовића препоручује се за лечење људи: камена, рана, за заустављање крви; користи се њено лишће и семе, употребљава се као састојак лековитог напитка и као прах.

H

невен (1. Calendula, $C$. arvensis, $C$. officinalis, 2. Helichrysum orienmale, 3. Хегаптиемим) <невенъ>. Једногодишња зељаста биљка, висока 30-50 сантиметара. Цвасти су жуте или наранцасте боје, појединачне, својственог мириса. У лековите сврхе употребљава се ивет, ређе цела биљка (Туцаков 1997: 514). К8ванъ невенъ у він8 растер8е бользаъ кад се намочи (48б). У лекаруши Косте Радовића препоручује се за лечење људи: болести ногу, отока на одређеним деловима тела, за спречавање дејства отрова, нарочито змије и бесног пса, за чишћење мокроте тела; користи се његов корен и цела биљка, употребљава се као састојак лековитог напитка и као облог.

\section{O}

opax (Juglans regia) <орахъ>. Opax расте самоникло или полусамоникло од југоисточне Европе до Јапана, просечна висина му је 25 метара. Сади се због масних и укусних семенки из којих се вади масно уље за јело и због скупоценог дрвета. У лековите сврхе употребљава се негов лист (Туцаков 1997: 522). Орахь [...]. Кога уЕде бесно псето нека 
надще срце Еде орахе и нека часть и нека часттъ изгрзшіи на ран8 меће неће м8 ce неће м8 се зла радити $\overline{\mathrm{G}}$ тога вк8са (49а). У лекаруши Косте Радовића препоручује се за лечење људи: уједа бесног пса, температуре, унутрашњих отока, унутрашње влажности, отечених ушију, ране настале од барута, за регулисање менструације и за тамњење косе; користи се његов плод са и без љуске као храна и као прах, сок добијен цеђењем зеленог ораха као састојак течности за испирање и течности за тамњење косе, као и сок добијен цеђењем његовог лишћа као течност за укапавање, затим уље добијено цеђењем ораха, његовог језгра, као средство за помазивање рана и његов лист као облог. Даје се савет и за успешно сађење ораха.

\section{П}

пастрњак (Pasminaca samiva) $<$ пастернякъ>. Двогодишња снажна зељаста биљка, висока 50-100 сантиметара. Гаји се у много варијетета. $У$ лековите сврхе употребљавају се плод и корен, ређе лист (Туцаков 1997: 534). Пастернякъ [...] корень нБговь кад се метне у

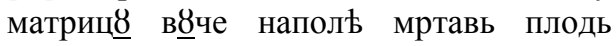
(51a). У лекаруши Косте Радовића препоручује се за лечење људи, одређеније само жена: болести материце и за избацивање мртвог плода из ње; користи се његов корен и семе као састојак лековитог напитка.

пасуљ (Phaseolus, Ph. vulgaris) $<$ пасуљ*> ${ }^{10}$. Гаји ce $y$ огромним количинама у разним варијететима ради исхране. Донесен је из Америке. У

${ }^{10}$ Форма забележена другим рукописом. лековите сврхе користе се његове зреле махуне без семена (Туцаков 1997: 532). 77 лишћа од пасуља истући и cofт исцедити и да пије пре грознице, а лук да се ольушти на пираје, да се посоли, да стоји 6 сати и на дену и на другу руку и пупак превије (71б). У лекаруши Косте Радовића препоручује се за лечење кашља код људи; користи се сок добијен цеђењем његовог листа који се пије.

пелен (Armeмisia, A. absinmhiuм) $<$ ппеленъ*>. Једна од најстаријих $u$ најцењенијих лековитих биљака. То је дуговечна, зељаста, врло разграната биљка, висока 0,5-1,5 метра. Цела биљка је обрасла свиластим длачицама, Приземно лишће је крупно, троперасто и има дугачке дрике. Лишће на горњем делу стабљике има кратке дрике, двоперасто је или једноперасто, а окрајции су лопатичасти или копљасти. Цвасти су удружене у рачвасте метлице са малим, лоптастим жутим главицама на кратким дршкама. На длакавом иветишту има много ияевастих, жутих ияветића са жлездама напуњеним уљем. Расте као коров по пољима, а нарочито по сувим, сунчаним, плитким и каменитим падинама (Туцаков 1997: 535-536). Кад се у ніой преко ноћъ метне пелена и смрекова ягода да се уютр8 перженимъ хльбомъ ужива чисти све влажности стомаха и fлегм8 (53б). У лекаруши Косте Радовића препоручује се за лечење људи: влажности стомака и чишћење флегме.

перуника дивија (Iris, I. pseudacorus) $<$ пер8ніка дівія>. Перунике су дуговечне, зељасте врло лепе украсне биљке са јаким ризомом, ситним корењем, сабљастим усправним листовима, 
округластом стабљиком и крупним иветовима тамноплаве, ьубичасте $и$ беле боје. У лековите сврхе користи се юен ризом (Туцаков 1997: 538). Пер8ніка дівія или питома кад се коренъ у прахъ сатрети и $1 / 2$ лота у шербет8 или він8 помаже затворенимъ персима (50а). У лекаруши Косте Радовића препоручује се за лечење људи: плућних болести, флегме, камена, за регулисање менструације, за избацивање глиста; користи се њен корен као прах и као састојак лековитог напитка. Истиче се и леп мирис који даје.

\section{перуника питома (Iris germanica)} <пер8ніка питома>. Перунике су дуговечне, зељасте врло лепе украсне биљке са јаким ризомом, ситним коренем, сабљастим усправним листовима, округластом стабљиком и крупним цветовима тамноплаве, ьубичасте и беле боје. У лековите сврхе користи се ьен ризом (Туцаков 1997: 538). Пер8ніка дівія или питома кад се коренъ у прахъ сатрети и $1 / 2$ лота у шербет8 или він8 помаже затворенимъ персима (50a). У лекаруши Косте Радовића препоручује се за лечење људи: плућних болести, флегме, камена, за регулисање менструације, за избацивање глиста; користи се њен корен као прах и као састојак лековитог напитка. Истиче се и леп мирис који даје.

пинпинела (Pimpinella мajor) $<$ пинпінела>. Биљка из породице ружа, мирисавог лишћа и плода, оскорушища (Р4: 210). Вода $\overline{\mathrm{G}}$ ист8чене пинпінеле исцећена Есть добра лице прати Еръ чисти и растер8е сваке пеге (51б). У лекаруши Косте Радовића препоручује се за лечење људи: болести црева и материце, бубрега, камена, рана, за смиривање стомака, за терање вина из организма, за чишћење лица и третирање пега, за побољшање лактације код жена; користи се њен плод као састојак лековитог напитка и сок добијен његовим цеђењем као течност за умивање.

подорожна буквица <подорожна б8квіца>. Зељаста биљка, трава (51а). Подорожна б8квіца[...] лечи све вн8трень ране (51a). У лекаруши Косте Радовића препоручује се за лечење људи: болести црева, унутрашњих рана, бубрега, крвавог урина, епилепсије, нечистих рана, главобоље, зубобоље, за регулисање лактације код жена; користи се њен корен, семе, цела биљка и сок добијен њеним цеђењем као храна, састојак лековитог напитка, као облог и као течност за испирање. Види боквица (= боквица, буква трава).

поморанша (Cimrus auranтіuм) $<$ поморанча>. Махом трновита зимзелена дрвета пореклом из Индије $и$ јужне Кине. Богат извор витамина $C$. Користи се за исхрану, а у лековите сврхе употребљава се юена кора, листови, иветови, етарска уља и иели плодови (Туцаков 1997: 556). Поморанча [...] огань и жећь гаси (50б). У лекаруши Косте Радовића препоручује се за лечење температуре и жеђи код људи; користи се сок добијен цеђењем њеног плода.

проја / просо (Рапісим міliacеим) $<$ проя>, <просо*>. Биљка са иветом у облику метлице са ситнозрнастим плодом који се употребљава као храна за животиье и људе (Р5: 223). 1. Проя [...] У кога утроба ніе здраво нека жіве прое угрее и нека на терб8х метне престаће м8 бользнъ $(50 б, 51 a) .2$. Да 
узме 1 лонацъ $\bar{G}$ сайтлика да нап8ни воде и проса целогъ заЕдно са кореномъ да метне (64б). У лекаруши Косте Радовића препоручује се за лечење људи: болести утробе и грознице; користи се као облог и као храна, тј. напитак.

пшеница (Trimicuм, T. vulgare) $<$ пшеница>. Житарица из породице трава и зрње те биљке из ког се добија брашно које се користи за исхрану (Р5: 314). Пшеница [...] Ф̄ пшенице начинънъ (...) и к8ванъ у води и шећер8, и како чорб8 здълавшіи есть полезно онимъ кой блюе крвъ и грло пром8кла Ec8 (50 б). У лекаруши Косте Радовића препоручује се за лечење промуклости грла и заустављање повраћања крви; користи се као храна.

\section{$\mathbf{P}$}

растовина / растово дрво (Quercus, $Q u$. robur, Qu. sessiliflora) <растовіна>, $<$ растово дрво*>. Храст,листопадно дрво са више варијетета чија се кора, потпуно глатка са младих стабљика, и плод, жир или шишарка, користе у лековите сврхе (Туцаков 1997: 664-665). 1. Растовіна [...] $\overline{\mathrm{G}}$ нъ ск8вана у млек8 кора пртіво (...) Еь свакоме Ед8. 2. Када жена м8чно вод8 п8шћа да успе віно на растовомъ угльвлю пакъ да п8ста С̈Оздолъ крозъ решето у себе добро ће се помоћи [...] $\bar{G}$ тога (...) дрвета (52б). У лекаруши Косте Радовића препоручује се за лечење људи: рана, зуба и вилица, за неутралисање отрова, за избацивање воде, за заустављање повраћања, за регулисање уринирања, за потамњивање косе; користе се његова кора и плод као састојци лековитог напитка, као облог и као прах. (= жир, шишарка). розмарин (Rosmarinus officinalis) <розмаринъ>. Рузмарин је густ, увек зелен, разгранат грмић, висок 1-2 метра. Цвета преко целе године ситним плавичастим цетићима. Цела биљка је пријатног мириса. Најбујније се развија у приморју и на острвима Јадранског мора, а затим свуда око Медитерана. У лековите сврхе користе се ґегов лист и етарско уље (Туцаков 1997: 581). Розмаринъ[...] врло добро изьгонява све излишно (53б). У лекаруши Косте Радовића препоручује се за лечење људи: стомачних болести, болести јетре и слезине, мозга, неутралише отров и даје снагу; користи се као састојак лековитог напитка.

ротква (Raphanus, R. samivus) <ротква>. Ротква је храна, зачин и народни лек. $У$ лековите сврхе употребљава се сок добијен иеђењем и юено семе (Туцаков 1997: 580). Ротква к8вана у води и медомъ заслаћена кад се піе нъколіко дана засобце помаж8 вр. стар8 кашлю и тера изъ персію боле гнилость (53a). У лекаруши Косте Радовића препоручује се за лечење људи: старог кашља, бола у грудима и плућних болести, камена, болести црева, канцера, уједа змије; користи се као храна, састојак лековитог напитка и као облог.

ружица (Rosa canina, R. rubiginosa, $R$. sempervirens $^{11} \quad<$ ружіца>, $<$ р8жіца*>.

${ }^{11}$ Код Симоновића наводи се неколико латинских назива за ружу (1. Iris, I. germanica, 2. Ophrys, 3. Rosa canina, $R$. rubiginosa, R. sempervirens, 3. Stachys maritime), међутим, с обзиром на то да je перуника посебно обрађена у рукопису, са сигурношћу би се могли 
Украсна баштенска, култивисана или шумска трновита биљка из породице ружа с мирисним ияветовима разне боје (P5: 572). Ружіца [...] убія у (...) глисте. [...]. С8ва р8жіца у він8 к8вана и марамомъ омочена глава прівіена болестъ ея утолява (52a). У лекаруши Косте Радовића препоручује се за лечење људи: главобоље, отока, крвавог кашља, несвестице, болести очију, зуба и грла, за избацивање цревних паразита; користи се ружина водица, тзв. ђулс, лишће, цвет као састојак лековитог напитка, као облог и као течност за укапавање и за испирање.

руј / рујевина (Cominus coggygria, = Rhus, Rh. coriaria) <р8йъ*>, <р8евіна> До три метра висок, врло разгранат и отпоран грм, обрастао округластим, глатким листовима који у јесен почрвене. Цветови су зеленкасти и ситни, удружени у крупне расперјане цвасти на врховима грана. Плод је једносемена, јајаста, зелена коштуниияа. Цвета од маја до јуна. Расте на сувим, каменитим, сунчаним странама. У лековите сврхе користе се лист и кора (Туцаков 1997: 582). Р8евіна $[. .$.$] . Езгро р8ево ск8вай добро у$ чистой води и томъ водомъ перати з8бе хоћед8 умін8ти (52б). У лекаруши Косте Радовића препоручује се за лечење зубобоље код људи; користи се као састојак течности за испирање.

\section{C}

салата (Lacmuca, L. samiva) <салата> Салата је двогодишња зељаста биљка,

изузети латински називи који се на њу односе, као и они чији описи биљака на које се односе не одговарају опису биљке датом у лекаруши. која се гаји и употребљава прве године као пресно поврће (Туцаков 1997: 587). Како к8вана салата и Едена умекшава затворен8 и врло полз8еть 8троби (55a). У лекаруши Косте Радовића препоручује се за лечење људи: затворене и болесне утробе и несанице.

cacaфpaca (Sassafras officinale) $<$ cacafpaca>. Дрво висине до 6 метара из атлантског појана Америке, чија се кора и дрвени део корена употребљавају у медииини. У Европи је украсна, а на југу Франиуске расте $u$ по шумама (Симоновић 1959: 420). Cacafpaca у самой води к8вана 1 литр8 и 3 или 4 холба воде и добро сварена Есть добро пити $\bar{G}$ кашля (56б). У лекаруши Косте Радовића препоручује се за лечење кашља код људи.

слатки бадем (Prunus coммunis) $<$ слатки бадемъ*>. Дрво коштуњава плода које се гаји у топлијим крајевима. Расте до 5 метара висине, листови су му дугуљасти, ииљасти, по рубу оштро тестерасти, иветови ружичасте боје, а плод је дугуљаста коштуница у којој се налази једна, ређе две, семенке. У семену слатког бадема има мало више шећера и уља, али нема ичијаногенетских хетерозида. Пореклом је из Мале Азије u Месопотамије, одакле се раширио свуда око Средоземног мора. $У$ лековите сврхе користи се уље добијено цеђенем његовог семена (Туцаков 1997: 221-222). $\overline{G \Xi}$ слаткихъ бадема зейтинъ добарь есть врло ради вн8тренихъ бользни како протиеци материце и прогая кад се тога зейтина $1 / 2$ сайтлика попіе (39a). У лекаруши Косте Радовића препоручује се за лечење људи: унутрашњих болести, за олакшавање порођаја, чишћење утробе, груди и јетре, ублажавање бола десни и главе, 
оспица на лицу, санирање инфицираних рана и рана од уједа бесног пса; користи се као храна, затим уље добијено цеђењем, као састојак смесе за облог.

семе $<$ семе>. Заметак, клица биљке која се ствара после оплодње, из које се развија нова биљка (P5: 730). Семе $\overline{\mathrm{G}}$ ньга са ситнимъ грожћемъ Едено помаже противъ несвестице (45a).

сирак (Sorghuм, S. сегпиим, $S$. saccharamuм, S. vulgare) <сиракъ>. Биљка пореклом из Арабије и Индије, једна од основних житарица за справљање хлеба у већем делу Африке (Симоновић 1959: 446). Тимъ сиркомъ разганяю се г8ше на врат8 сльд8ющімъ начиномъ [...] (55б). У лекаруши Косте Радовића препоручује се за лечење људи: разбијање гуша на врату и регулисање менструалног крварења; користи се његов цвет и цела биљка као састојак лековитог напитка и као храна.

ситна рута (Ruma graveolens) < ситна рута $>^{12}$. Рутвица или седеф је дуговечна зељаста биљка, висока до 80 сантиметара. Цветови су зеленожућкасти и налазе се удружени у цввасти на врху стабљике. Плод је чаура. Гаји се и као мирисно и као украсно иввће, зачин и лековита биљка. Лековита је и отровна. У лековите сврхе користи се лист, ређе врхови гранчица у ияету и семе (Туцаков 1997: 585). Ситна рута [...] од фраса скуваи теи и подаи детету да помало пије (71a). У лекаруши Косте Радовића препоручује се за лечење фраса код детета; користи се припремљена као чај.

${ }^{12}$ Форма забележена другим рукописом. слачица (Brassica nigra) ${ }^{13}<$ слачица>. Црна слачица се гаји, а расте и дивља $и$ полудивља готово свуда. То је једногодишьа биљка, висока до једног метра. Цвета жутим световима од маја до августа. Користи се ьено зрно и семе (Туцаков 1997: 608). Слачица [...] поправля сл8хь и растер8е ш8мь (55a). у лекаруши Косте Радовића препоручује се за лечење људи: за бељење коже руку и поправљање слуха; користи се њено семе стучено у прах. (= горушица).

слезовача (Almhaea rosea, Malva, M. silvesmris) <слезовача>. Бели и ирни слез. Бели слез је дуговечна зељаста биљка висине 1-2 метра. Цела биљка је обрасла свиластим длакама, тако да су листови сребрнобеличасти; стабљика је права или разграната, при дну одрвенена. Листови су спирално поређани, а из юихових пазуха при врху стабљике и огранака избијају ките бело-ружичастих иветова. Цвета преко целог лета. У лековите сврхе употребљавају се лист и корен (Туцаков 1997: 612). Црни слез је најобичнија биљка веома распрострањена, ружичастовубичастих иветова, обраслих длакама и жездастим главичастим длакама. Плоднииа је округла, спљоштена и има много преграда. У лековите сврхе користи се ґегов ияет (Туцаков 1997: 616). Слезовача са лишћемъ і кореньмъ к8ванъ добра е да се члкъ к8па и пари, Еръ Фтвара вн8тренъ саставе, отоке и п8ть чини бешики (54б). У лекаруши

13 С обзиром на то да се у запису наглашава када се мисли на белу слачицу, вероватно се под појмом слачица мисли на црну. 
Косте Радовића препоручује се за лечење људи: отока, бешике, материце, десни и зуба, избацивање сувишне влажности главе; користе се њен корен и лист као састојак течности за купање и као прах за прање зуба и десни.

смоква (Ficus carica) <смоква>. Смоква расте дивље, а и узгаја се у облику дрвета или густог грма. Има крупне, тамнозелене, дубоко издељене листове кожне конзистенције. Успева и на најмршавијем тлу, а највише се гаји у топлим пределима. У лековите сврхе користи се юен плод (Туцаков 1997: 617-618). Кога м8чить каменъ или песакъ нека на дще Едн8 или 2 смокве біберомъ пос8те Еде помоћи ће м8 (54a). У лекаруши Косте Радовића препоручује се за лечење људи: камена и песка, кашља, за регулисање протока крви; користи се као храна и као састојак лековтиг напитка.

смола <смола*>. Лепљива маса, безбојна или жуте до смеђе боје коју луче четинари и неке друге биљке и која на ваздуху отврдне (Р5: 889). Вишня и трешня раћаю смол8 коя 8 сирћет8 ск8вана ш8г8 лечи и красте на тъл8 (40б).

смрека (Juniperus, J. соммипis, J. nana, J. oxycedrus, Picea excels) <смрека> Зимзелен грм из породице чемпреса са тврдим, ииљастим иглицама, чији се плод, ирвене $и$ ирне бобице, употребљава за прављење ракије (Р5: 894). Смрека у бел8 він8 к8вана и піена помаже флегматік8 стомах8 (54a). У лекаруши Косте Радовића препоручује се за лечење људи (болести стомака, материце, плућа, утробе, кашља, сувишне воде и камена, неутралише отров) и за заштиту од змија и других отровних животиња; користи се као састојак лековитог напитка или лековите масти.

смрекова јагода <смрекова ягода> Вероватно се односи на плод смреке, юене ирвене и ирне бобице. Кад се у ніой преко ноћъ метне пелена и смрекова ягода да се уютр8 перженимъ хльбомъ ужива чисти све влажности стомаха и fлегм8 (53б). У лекаруши Косте Радовића препоручује се за лечење људи: влажности стомака и чишћење флегме. Види смрека. (= смрека).

спанаћ (Spinacia oleracea, S. spinosa) <спанаћъ>. Врста поврћа, једногодишња зељаста биљка чије се лишће употребљава као храна (Р5: 924). К8ванъ спанаћъ и на жел8дацъ прівіенъ како fластеръ умалюе оганъ и бользнъ у нђм8 (55а). У лекаруши Косте Радовића препоручује се за лечење људи: сваке нечистоће, влажности и флегме, за ублажавање температуре и бола у желуцу; користи се као облог и као храна.

T

тамјан (Boswellia, Boswellia serrama) $<$ таміанъ>. У питању је род Boswellia из p. Burseraceae, који обухвата више врста ниских гранатих дрвета, чија смола, горког укуса и карактеристичног мириса, од давнина служи за кађење при верским обредима. Расте на иироком пространству од Индије, преко јужне Арабије, до Eтиопије и Сомалије (Драгин 2014: 16). С таміаномъ и смірномъ и шафраномъ помъшавшіи да се жена $\overline{G 0}$ дол8 помаже Ей на почетку Ечмене и пороћеня (43б). У лекаруши Косте Радовића препоручује се за лечење људи: рана, болести очију, олакшавање порођаја; 
користи се као прах и као састојак лековите масти и течности за укапавање. (= тамјан бели).

тамјан бели <тамјан бели $>^{14}$. [... тамјан бели [...] (72a). Види тамјан. (= тамјан).

тиква (Cucurbima, C. меlopepo, Lagenaria vulgaris) <тиква>. Једногодишња баштенска биљка из истоимене породице са више врста и плод те биљке који се користи за исхрану људи и стоке, а његово семе за добијање лековитог уља (Р6: 207). Тиква и б8ндеве кора у пепел8 спальна естъ лековито тим пепеломъ гнил8 ран8 насипати (58a). У лекаруши Косте Радовића препоручује се за лечење људи: рана и инфицираних рана; користи се као прах.

трава <трава>. Зељаста једногодишња или вишегодишња биљка из истоименог рода монокотила, којих има врло много врста, са танким, шупљим, коленастим стаблом (Р6: 248). Раст8 у водену мест8, к8вана та трава естъ добра да се жена коя родна рада бити такоже и да піе (60a).

трешња (Phaseolus coccineus, Prunus aviuм $^{15} \quad<$ трешня>. Листопадна дрвенаста биљка, воћка из породице ружа са слатким округлим коштичавим плодом и плод те биљке (Р6: 285). Вишня и трешня раћаю смол8 коя 8 сирћет8 ск8вана ш8г8 лечи и красте на тъл8 (40б). У лекаруши Косте Радовића

\footnotetext{
${ }^{14}$ Форма забележена другим рукописом.

15 Први латински назив се односи на врсту варива (Симоновић 1959: 346), тако да је сигурно реч о другом.
}

препоручује се за лечење људи: шуге и краста по телу; користи се смола трешњевог дрвета, припремљена као течност за испирање.

трњина (Acacia arabica, Prunus spinosa, Robinia pseudacacia) <тернина $>$, $<$ трнина*>. Трновит, врло отпоран, веома разгранат и густ грм, висок 1-3 метра, обрастао ситним издуженим јајастим, по ободу тестерастим листовима. Цветови су многобројни, ситни и бели. Плод је округла, готово ирна, око 1 сантиметра велика кочтуница прекривена беличастим воштаним пепељком; укуса је опорог и киселог. Цвета током марта и априла. У лековите сврхе користе се ивет, зрео плод и ређе кора (Туцаков 1997: 651). Тернина [...] GО тьхь трнина исцећена вода кад се какво мъсто ніомъ помаже гдђ ніе рад имати косе не да растити (57a). У лекаруши Косте Радовића препоручује се за лечење људи (крвавих отока, испирање уста и грла, за регулисање менструалног крварења, за болести материце и дебелог црева, за спречавање длакавости) и за поправљање укуса вина; користи се сок добијен цеђењем плода, плод и кора као састојак лековитог напитка или течности за испирање.

трска (Arundo donax, Phragmimes соммипіs) <трска>. распрострањена барска биљка, висока до 4 метра. У лековите сврхе користи се юен ризом (Туцаков 1997: 653). Лишће СО трске зелене кад се ист8че и прівіе лечи огнъвите отоке и излишни оганъ (57б). У лекаруши Косте Радовића препоручује се за лечење људи: отока и температуре, за извлачење трња, ексера и дрвета из тела; користе се њен корен и лишће као облог. 
$\mathbf{y}$

урма (Phoenix dacmylifera) <урма*>. Урмено дрво. Високо дрво које расте у тропским и суптропским областима, а препознаје се по круни од лепезастог лишћа на врху витког, правог и неразгранатог стабла. Ценено је због свог плода, сока који се добија из засеченог стабла, дрвета и лишћа који се користе за израду разних предмета за домаћинство (Драгин 2014: 23). [...] $1 / 2$ урме fришке (65б). У лекаруши Косте Радовића препоручује се за лечење туберкулозе код људи; користи се њен плод као један од састојака лека.

Ф

феникулум (Foeniculum vulgare) ${ }^{16}$ $<$ фенік8л8мъ>. Коморач, веома важна лековита, ароматична, зачинска, медоносна, хранљива и индустријска биљка која се гаји на великим повриинама. У лековите сврхе користи се његов плод (Туцаков 1997: 486). Фенік8л8мъ [...] раствара крвь г8ст8С убоя (58б). У лекаруши Косте Радовића препоручује се за лечење људи: унутрашњих болести, највише камена, болести очију, подлива насталих од ударца, за побољшање лактације код жена; користи се његово лишће и стабло, употребљава се сок добијен цеђењем, и као састојак лековитог напитка.

${ }^{16}$ Код Симоновића наводи се неколико латинских назива за коморач (Crithmum maritimum, Daucus, Foeniculum vulgare, Pleurospermum austriacum), међутим, с обзиром на назив који је наведен у рукопису, а који је заправо латински назив биљке, нема сумње о којој биљци је реч.
$\mathbf{X}$

хрен (Arмoracia lapamhifolia, A. мастосагра) <хренъ>. Рен расте по влажним местима готово широм целог света. Гаји се због корена који служи за зачин, а који је дебео до 6 сантиметара и дугачак око 1 метра, жућкасто-сиве боје. То је снажна зељаста вишегодишња биљка која расте до једног метра. Има врло велике, по ободу назубљене листове и дугачке ивасти са белим ситним иветовима. У лековите сврхе употребљава се његов свеж корен (Туцаков 1997: 573). Хрень [...] сілно тера камень, и вод8, и женамь месечин8 (58б). У лекаруши Косте Радовића препоручује се за лечење људи: камена, сувишне воде у организму, за регулисање менструалног циклуса; користи се као састојак лековитог напитка.

Ц

цвет <цветъ>. Орган размножавања код биљака који се често одликује живим бојама и пријатним мирисом (Р6: 767). [...] кріновъ цветъ у лютой ракіи са камfоромъ дистілірати добаръ есть прівіяти на fришк8 ран8 не да се подзледити и тако скоро лечить (42б).

цветнасти кељ или карфиол (Brassica oleracea bomrymis cauliflora) <цветнасти кель или карfi[ол]*>. Цветача, иветни куnус (Р2: 672). Цветнасти кель или карfi(...) [...] повраћа сл8хь (59а). У лекаруши Косте Радовића препоручује се за лечење људи: враћа ослабљени слух, за лечење рана насталих услед оболелости од канцера; ${ }^{17}$ користи се сок

17 У запису рецепта користи се реч живіна која је у средњовековној медицинској терминологији означавала 
добијен цеђењем као течност за укапавање и као храна.

цимет (Сіппамомим cassia, C. сеуlaпiсим) <ціметь*>. Кора врло пријатног мириса и слатког, топлог укуса добијена од разних врста рода Сіппамомим из тропске Азије. Много се иени као зачин и пријатан ароматик (Туцаков 1997: 668). [...] 2 цімета $1 / 2$ лота [...] (60б). У лекаруши Косте Радовића препоручује се за лечење срдобоље код људи.

цитрон (Cimrus, C. liмопим) <цітронъ*>. Лимун, зимзелено дрво кожастих листова и округластих жутих киселих плодова, суптропска воћка; ьен плод (Р3: 208). Пореклом је из северне Индије или Персије. У лековите сврхе користе се његова кора, уље и сок (Туцаков 1997: 556). Цітрони [...] против8 Еда (58б). У лекаруши Косте Радовића препоручује се за лечење људи: спречава дејство отрова, бистри меланхоличну крв, побољшава дах, даје леп мирис; користи се као храна и сок добијен цеђењем његовог семена као састојак лековитог напитка.

\section{$\mathbf{Y}$}

чичак (Agrimonia eupamoria, Almhaea rosea, Aremonia agrimonioides, Lappa, L. major, Turgenia lamifolia, Xanmhiuм spinosuм, X. sтruмагіuм) <чичакъ>. Врста биљке из породице главочика са главицама на врху стабљике које се лако закачињу за животињску вуну или длаку, за одело (Р6: 888). Мали чичакъ к8ванъ у води добаръ естъ противъ ж8те

канцер, рак (Катић 1990: 10). Може се претпоставити да и овде има исто значење. больсти да се нимъ человекъ триредъ ок8па и напари, и тп у сред8 после полдне у 1. ви или 8. часъ, у четвертаг у 12. часъ, у петакъ у 6 . часъ рано, хоће се избавити (59a). У лекаруши Косте Радовића препоручује се за лечење жутице код људи; користи као састојак воде за купање.

\section{III}

шаргарепа (Daucus caroma hormensis) $<$ шаргарепа>. Двогодишьа повртарска биљка из породице ититара $c$ вретенастим задебљалим ирвенкастожућкастим кореном који се употребљава као храна (Р3: 441). Шаргарепа [...] тера урин8 и женамь месечин8 (59б, 60а). У лекаруши Косте Радовића препоручује се за лечење људи: болести плућа и кашља, за регулисање уринирања и менструалног крварења; користи се као храна.

шафран (Crocus, C. banamicus, C.neapolimanus, C. samivus) <шаfранъ*>. Шафран је дуговечна биљка. Из округле, чврсте, кртоласте луковице избија најпре неколико дугуљастих листова, а затим у юиховој средини 2-3 крупна вубичаста ивета. У ивету се види жут тучак са три крупна црвена жига. Цвета у јесен. Има вите ботаничких и трговачких врста шафрана. Одавно се гаји у Персији, Индији, Малој Азији, одакле је пренесен у Европу. У лековите сврхе употребљавају се његови жигови (Туцаков 1997: 678). С таміаномъ и смірномъ и шаfраномъ помьшавшіи да се жена $\bar{G}$ дол8 помаже Ей на почетку Ечмене и пороћеня (43б). У лекаруши Косте Радовића препоручује се за олакшавање порођаја; користи се као састојак лековите масти. 


\section{шишарица}

<шішаріца*>.

Употребљавају се шишарке с разних врста храста у ветерини, у хуманој медицини и у индустрији (Туцаков 1997: 684). Шішаріце $\widetilde{G}$ тога истогъ дрвета у прахъ ист8ћи добро е сипати у ран8 Еръ чисти гнилость (52б). У лекаруши Косте Радовића препоручује се за лечење рана код људи. Види храст, жир. (= храст, жир).

шљива (Prunus doмesmica) <шлива>. Листопадно дрво које се гаји у разним одликама због укусних плодова. У лековите сврхе користи се зрео плод ильве, свеж или осушен (Туцаков 1997:
683). Шлива $[\ldots]$ умегшава м8 огань у усти и гаси жећь (59б). У лекаруши Косте Радовића препоручује се за лечење људи: за болести утробе, температуре и ублажавање жеђи; користи се као храна.

шумови <ш8мови>. Трава која расте $y$ воденом месту (Радовић 1830: 60а). Ш8мови [...] добра да се жена коя рада родна бити такоже и да піе (60а). У лекаруши Косте Радовића препоручује ce за побољшање плодности код жене; користи се као састојак лековитог напитка.

\section{6. Закључак}

\section{1. Лековито биље и њихови називи у лекаруши Косте Радовића}

На крају састављања речника долази се до податка да у лекаруши Косте Радовића постоји укупно 109 фитонима за 93 различите биљне врсте којима се приписује лековито дејство и њихове вегетативне делове који се користе за справљање лека (корен, лист, плод, цвет, семе, кора).

На основу броја рецепата који се препоручују за справљање лека са одређеном биљком, тј. на основу броја болести које се одређеном биљком лече, може се закључити да су омиљене лековите биљке у овој лекаруши: црни лук, орах, винова лоза (десет рецепата), лан, смрека (девет рецепата), бадем (осам рецепата), ружа, ротква (седам рецепата), бели лук, бресква, буква, трњина, храст (шест рецепата). Биљке чија лековитост није толико обухватна углавном су оне биљне врсте чији плод није био јестив, као што су нпр. рујевина, јасен, бор, брест, зова, чичак, или је био највећим својим делом употребљаван у исхрани као лако доступна храна, као што су нпр. кајсија, трешња, вишња, лешник, пшеница, пасуљ (биљне врсте које су расле или се узгајале као домаће), или биљне врсте које су биле тешко доступне, с обзиром на место њихове распрострањености, као што су нпр. цимет, урма, поморанџа (по један рецепт). По један рецепт је забележен и за рен и жалфију, што не одговара високом степену лековитости који се тим биљкама 
данас научно признаје, као и кукољу и маку, вероватно због њихове велике отровности, тј. опојног дејства.

\section{2. Лековито биље у лекаруши Косте Радовића и средњовековној лекаруши - подударања и одступања}

Утицај средњовековних терапијских кодекса, лекаруша, на настанак нових, па и оних најмлађих, потврђен је и у случају лекаруше Косте Радовића. Поређењем лековитих биљака и болести за чије лечење се оне препоручују из лекаруше Косте Радовића са лекарушом Ходошког зборника, као нашом најстаријом лекарушом, уочава се подударност у коришћењу одређених биљних врста, с тим да се разлике уочавају на пољу лековитих својстава која им се приписују. ${ }^{1}$

Резултати до којих се долази показују да се истих двадесет и девет биљних врста појављује у обе лекаруше (бадем, бибер, боб, бресква, бундева, винова лоза, врба, диња, дуд, измирна, коприва, кукољ, купус, лан, лишај плућњак, лук бели, лук црни, пелин, ротква, ружа, слачица, смоква, тамјан, тамјан бели, трешња, трска, урма, шафран, шишарке (храст)) са следећим лековитим својствима: ${ }^{2}$

- бадем - у лекаруши Ходошког зборника препоручује се за лечење красти (Катић 1990: 11) и пијанства (Катић 1990: 17), док се у лекаруши Косте Радовића препоручује за лечење флегме у грудима и стомаку, песка (бадем горки), унутрашњих болести, за олакшавање порођаја, чишћење утробе, груди и јетре, ублажавање бола десни и главе, оспица на лицу, санирање инфицираних рана и рана од уједа бесног пса (слатки бадем);

\footnotetext{
${ }^{1}$ Лекаруша Ходошког зборника није обрађена у целини, већ је реч о избору који је приредио и на савремени језик превео Реља Катић (1990). Није навођен оригинални текст, тако да није било могуће упоредити фитониме из лекаруше Косте Радовића са средњовековним. То за последицу има непотпуност информације, али и податак добијен на основу предузетог поређења са одломком, а не чак и целовитим делом, потврђује повезаност најмлађих лекаруша са најстаријим.

2 Треба имати на уму да би број биљних врста које се јављају у обе лекаруше био сигурно већи када би се за поређење узела цела лекаруша Ходошког зборника, што овом приликом није учињено.
} 
- бели лук - у лекаруши Ходошког зборника препоручује се за лечење кашља (Катић 1990: 9), рана (Катић 1990: 10), болова у јетри (Катић 1990: 22) и за избацивање пијавица (Катић 1990: 13), док се у лекаруши Косте Радовића препоручује за лечење куге, камена, за регулисање менструације, за одржавање хигијене, тј. сузбијање паразита;

- бибер - у лекаруши Ходошког зборника препоручује се за лечење главобоље (Катић 1990: 9), назеба (Катић 1990: 19), метастазирајућих апсцеса, тзв. гута, (Катић 1990: 22) и за изазивање кијавице (Катић 1990: 17), док се у лекаруши Косте Радовића препоручује за лечење камена и песка;

- боб - у лекаруши Ходошког зборника препоручује се за подмлађивање лица (Катић 1990: 10), док се у лекаруши Косте Радовића препоручује за лечење глувоће, отеклина, за негу лица;

- бресква - у лекаруши Ходошког зборника препоручује за лечење зубобоље (Катић 1990: 8) и за истеривање црва из уха (Катић 1990: 14), док се у лекаруши Косте Радовића препоручује за лечење камена, очију, ушију, чишћење груди (плућа), спречавање опијања од вина;

- бундева - у лекаруши Ходошког зборника препоручује се за лечење зубобоље (Катић 1990: 8), болова у очима (Катић 1990: 18) и камена (Катић 1990: 20), док се у лекаруши Косте Радовића препоручује за лечење рана и инфицираних рана;

- винова лоза - у лекаруши Ходошког зборника препоручује се за лечење тровања са гљивама (Катић 1990: 19), камена (Катић 1990: 20), жутице (Катић 1990: 20) и слезине (Катић 1990: 22), док се у лекаруши Косте Радовића препоручује за лечење камена, болесних очију, желуца, температуре, болести главе, претераног повраћања, за побољшање апетита и одржавање чистоће тела;

- врба - у лекаруши Ходошког зборника препоручује се за лечење слезине (Катић 1990: 22), док се у лекаруши Косте Радовића препоручује за лечење брадавица и жуљева, против зачећа, за чишћење лица и очију;

- диња - у лекаруши Ходошког зборника препоручује се за лечење дијареје (Катић 1990: 13), док јој се у лекаруши Косте Радовића не приписује лековито дејство; 
- дуд - у лекаруши Ходошког зборника препоручује се за лечење опекотина (Катић 1990: 21) и слезине (Катић 1990: 22), при чему се наглашава да је реч о црном дуду, док се у лекаруши Косте Радовића препоручује за лечење зубне болести и температуре, грознице;

- $\quad$ измирна - у лекаруши Ходошког зборника препоручује се за лечење прелома кости (Катић 1990: 9), док се у лекаруши Косте Радовића препоручује за одржавање хигијене усне дупље, олакшавање порођаја, промуклости и кашља, поквареног стомака, одржавање здравља зуба и десни, лечење рана, поготово на глави;

- $\quad$ коприва - у лекаруши Ходошког зборника препоручује се за лечење кашља (Катић 1990: 9), рана (Катић 1990: 10) и отока целог тела (Катић 1990: 14), док се у лекаруши Косте Радовића препоручује за лечење бола у боковима, унутрашњих рана, кашља, тескобе у грудима, болести уринарног тракта;

- кукољ - у лекаруши Ходошког зборника препоручује се за лечење назеба (Катић 1990: 9) и жутице (Катић 1990: 15), док се у лекаруши Косте Радовића препоручује за олакшавање порођаја жена;

- $\quad$ купус - у лекаруши Ходошког зборника препоручује се за лечење оспа у устима (Катић 1990: 9), отока целог тела (Катић 1990: 15), опадања косе (Катић 1990: 16), главобоље од вина и пијанства (Катић 1990: 17), док се у лекаруши Косте Радовића препоручује за лечење шуге, рана, глувоће, модрица и подлива, хладне грознице;

- лан - у лекаруши Ходошког зборника препоручује се за лечење болести црева (Катић 1990: 13) и болова у јетри (Катић 1990: 22), док се у лекаруши Косте Радовића препоручује за лечење несвестице, срдобоље, температуре, плућних болести, тзв. санчие, за заустављање крви, за ублажавање бола отока;

- $\quad$ лишај плућњак - у лекаруши Ходошког зборника препоручује се за лечење метастазирајућих апсцеса, тзв. гута, (Катић 1990: 21), док се у лекаруши Косте Радовића препоручује за лечење срдобоље, болести грла и зуба;

- пелен - у лекаруши Ходошког зборника препоручује се за лечење болова у очима (Катић 1990: 18), тровања са гљивама (Катић 1990: 19), жутице (Катић 1990: 20) и за регулисање уринирања (Катић 1990: 19), док се у лекаруши Косте Радовића препоручује за лечење влажности стомака и чишћење флегме; 
- ротква - у лекаруши Ходошког зборника препоручује се за заустављање крварења (Катић 1990: 11), док се у лекаруши Косте Радовића препоручује за лечење старог кашља, бола у грудима и плућних болести, камена, болести црева, канцера, уједа змије;

- $\quad$ ружа - у лекаруши Ходошког зборника препоручује се за лечење несанице, непријатног задаха из уста (Катић 1990: 11) и болова у јетри (Катић 1990: 22), док се у лекаруши Косте Радовића препоручује за лечење људи: главобоље, отока, крвавог кашља, несвестице, болести очију, зуба и грла, за избацивање цревних паразита;

- слачица - у лекаруши Ходошког зборника препоручује се за лечење главобоље (Катић 1990: 9), док се у лекаруши Косте Радовића препоручује за враћање покретљивости удовима, за спречавање вина да ускисне (слачица бела), за бељење коже руку и поправљање слуха (слачица црна);

- смоква - у лекаруши Ходошког зборника препоручује се за лечење старих рана (Катић 1990: 16) и болести слезине (Катић 1990: 22), док се у лекаруши Косте Радовића препоручује за лечење камена и песка, кашља, за регулисање протока крви;

- тамјан - у лекаруши Ходошког зборника препоручује се за лечење красти (Катић 1990: 11) и сунчанице (Катић 1990: 17), док се у лекаруши Косте Радовића препоручује за лечење рана, болести очију, олакшавање порођаја;

- тамјан бели - у лекаруши Ходошког зборника препоручује се за лечење грознице (Катић 1990: 8), задњег црева (Катић 1990: 15) и назеба (Катић 1990: 19), док се у лекаруши Косте Радовића препоручује за лечење рана, болести очију, олакшавање порођаја;

- $\quad$ трешња - у лекаруши Ходошког зборника препоручује се за лечење старих рана (Катић 1990: 19), док се у лекаруши Косте Радовића препоручује за лечење шуге и краста по телу;

- трска - у лекаруши Ходошког зборника препоручује се за лечење бола у очима (Катић 1990: 18), док се у лекаруши Косте Радовића препоручује за лечење отока и температуре, за извлачење трња, ексера и дрвета из тела; 
- урма - у лекаруши Ходошког зборника препоручује се за лечење зечије усне (Катић 1990: 14) и бола у јетри (Катић 1990: 22), при чему Катић наводи назив датула, док се у лекаруши Косте Радовића препоручује за лечење туберкулозе;

- црни лук - у лекаруши Ходошког зборника препоручује се за лечење старих рана и гасне гангрене (Катић 1990: 16) и камена (Катић 1990: 20), док се у лекаруши Косте Радовића препоручује за лечење кашља, куге, болести очију, пега, за побољшање раста косе, слуха, растеривање шума из главе, за заустављање крварења из носа, за регулисање уринирања код мале деце;

- шафран - у лекаруши Ходошког зборника препоручује се за лечење несанице (Катић 1990: 11) и главобоље од вина (Катић 1990: 17), док се у лекаруши Косте Радовића препоручује за олакшавање порођаја;

- $\quad$ шишарке (храст) - у лекаруши Ходошког зборника препоручују се за изазивање кијавице (Катић 1990: 17), док се у лекаруши Косте Радовића препоручује за лечење рана.

Приметно је да су лековита својства биљака наведена у лекаруши Косте Радовића бројнија и разноврснија у односу на она из средњовековне лекаруше, која често обухватају, што је сасвим очекивано с обзиром на пораст знања о лечењу лековитим биљем које је човек током векова, који ове две лекаруше деле, стекао. Посвећенији однос према лековитом биљу у лекаруши Косте Радовића видљив је и на нивоу организовања текста лекаруше, који се састоји од записа који су насловљени фитонимом, а тек при крају, и у малом броју, називом болести. Други описани начин организовања текста карактеристичан је за описану средњовековну лекарушу и сугерише да је у центру пажње средњовековног човека била болест, а затим лековито биље које ту болест лечи, док је у лекаруши Косте Радовића тај редослед другачији. У том смислу посматрана, лекаруша Косте Радовића на одређен начин је повезана са нашим првобитним средњовековним лекарушама, док, с друге стране, доноси и новине које употпуњују народно знање о лечењу лековитим биљем. 


\section{ЛИТ Е Р А Т У Р А}

Бјелаковић, Исидора (2003). Називи болести у лекарушама из XIX века са територије Војводине. Прилози проучаваюу језика. 34: 5-36.

Бјелаковић, Исидора и Љиљана Суботић (2011) Концепција дијахронијског терминолошког речника. У: Лексикологија, ономастика, синтакса (ур. Владислава Ружић, Слободан Павловић). Нови Сад: Филозофски факултет. 149-162.

Бојанин, Станоје (2012). Лечење биљем у средњовековној Србији. Основни преглед. Годишњак за друштвену историју. 19/1: 7-34.

Драгин, Наташа (2014). Страни називи биљака у списима старословенског канона. Зборник Матице српске за филологију и лингвистику.57/2: 13-38.

Катић, Реља (1957). О утицају српске средњовековне медицине на постанак новијих тераписких кодекса народне медицине код Срба. Зборник радова САН. 56/4: 99-117.

Катић, Реља (1990). Медицински списи Ходошког зборника. Београд: Народна библиотека Србије.

Радовић, Коста (1830). Лекаруша Косте Радовића. Рукопис.

Речник српскохрватског књижевног језика:

P1. Речник српскохрватскога књижевног језика, књига прва А-Е, Нови Сад Загреб: Матица српска - Матица хрватска, 1967.

Р2. Речник српскохрватскога књижевног језика, књига друга Ж-К, Нови Сад Загреб: Матица српска - Матица хрватска, 1967.

Р3. Речник српскохрватскога књижевног језика, књига трећа К-О, Нови Сад Загреб, Матица српска - Матица хрватска, 1969.

P4. Речник српскохрватскога књижевног језика, књига четврта О-П, Нови Сад: Матица српска, 1971.

P5. Речник српскохрватскога књижевног језика, књига пета П-С, Нови Сад: Матица српска, 1973.

P6. Речник српскохрватскога књижевног језика, књига шеста С-Ш, Нови Сад: Матица српска, 1976.

Савић, Александар (2014). Дарови са Нила: нови поглед на сусрет Светог Саве са египатским султаном. Зборник Матище српске за историју. 90: 7-35.

Симоновић, Драгутин (1959). Ботанички речник. Београд: Научно дело.

Станојевић, Владимир (1953). Историја медицине. Београд: Медицинска књига.

Туцаков, Јован (1997). Лечење биљем. Београд: Рад.

Roмano, Jaša (1973). Jugoslovenska bibliografija lekaruša $i$ narodnih medicinskih rukopisa. Beograd: Naučno društvo za istoriju zdravstvene kulture Jugoslavije. 
Čerpeкоvić, Zoran (2005). Srpska medicina u srednjem veku. Opšta medicina. 11/1-2: 82-84.

Šuleк, Bogoslav (1879). Jugoslavenski imenik bilja. Zagreb: Jugoslavenska Akademija Znanosti i umjetnosti.

Nikolina Tutuš

DICTIONARY OF PHYTONYMS IN KOSTA RADOVIĆ'S HEALING BOOK (1830)

\section{SUMMARY}

This paper presents a healing book with a prayer book written by Kosta Radović in 1830, which is kept in the Rarities department of Matica Srpska under the signature RR II 62. The aim of the research is to look at pre-standard language expression at the lexical level and to compose the dictionary of phytonyms represented in this manuscript. As a result, a systematic review of the herbs used for healing is obtained, as well as an overview of the language fund related to their naming. Comparison with older, medieval, medical books, such as the Hodoški zbornik and the Hilandarski tipik, seeks to shed light on the potential association of this manuscript with works of a similar purpose in the earlier period, using as criteria the organization of the text, the number and identity of the plant species, their names and medicinal actions attributed to them.

KEYWORDS: handwritten healing book with prayer book, Kosta Radovic, $19^{\text {th }}$ century, phytonyms dictionary.

Мср Николина Тутуш

Одсек за српску књижевност и језик Филозофски факултет, Универзитет у Новом Саду 